\title{
Multivariate Analysis of Confined Groundwater Hydrochemistry of a Long-Exploited Sedimentary Basin in Northwest China
}

\author{
Xuedi Zhang, ${ }^{1,2}$ Hui Qian, ${ }^{1,2}$ Hao Wu, ${ }^{1,2}$ Jie Chen, ${ }^{1,2}$ and Liang Qiao ${ }^{1,2}$ \\ ${ }^{1}$ School of Environmental Science and Engineering, Chang'an University, No. 126, Yanta Road, Xian, Shaanxi 710054, China \\ ${ }^{2}$ Key Laboratory of Subsurface Hydrology and Ecology in Arid Areas, Ministry of Education, No. 126, Yanta Road, \\ Xian, Shaanxi 710054, China \\ Correspondence should be addressed to Xuedi Zhang; zhangxuedi2007@163.com
}

Received 15 September 2015; Revised 18 January 2016; Accepted 8 February 2016

Academic Editor: Samuel B. Dampare

Copyright (C) 2016 Xuedi Zhang et al. This is an open access article distributed under the Creative Commons Attribution License, which permits unrestricted use, distribution, and reproduction in any medium, provided the original work is properly cited.

\begin{abstract}
A series of environmental and geological problems have been caused by overexploitation of confined aquifers (i.e., deep groundwater) in the Yinchuan region, northwest China. Accordingly, the characteristics of confined water were analyzed and collected from 33 sampling wells in spring of 2011, to determine the factors that influenced the composition and evolution of confined water, using principal component analysis (PCA), correlation analysis, groundwater evolution, and mineral dissolution/precipitation analysis. PCA showed that the hydrochemistry of confined water is controlled mainly by the dissolution of minerals, mixing between the confined aquifer and polluted phreatic water, and effects of ion exchange in the study area. The following management actions recommended were essential, in order to enable the sustainable exploitation of confined water: (1) gradually decreasing the amount of groundwater pumped from confined aquifer in the central part of the depression cone, (2) upgrading the quality of phreatic water, and (3) increasing artificial recharge of the groundwater system by flood waters in the Helan leaning pluvial plain.
\end{abstract}

\section{Introduction}

Groundwater resources, which are found in the loose sedimentary aquifers, often have good quality, are not easy to be polluted, are widely distributed, have large amount of exploitation, and have little variability among years [1]. They therefore serve as major sources of freshwater in many countries around the world, supporting so many needs for agriculture, industry, and municipal drinking $[1,2]$. However, with the soaring water demands for increasing industrialisation and urbanisation, the groundwater exploitation rises sharply, forming depression cones in some areas in the world; leakage recharge from other aquifers then occurs which is inevitable, providing an alternative source to compensate the increasing groundwater withdrawal $[1,3,4]$.

However, the groundwater hydrochemistry of sediment aquifers can be affected by multiple natural factors, such as chemical reactions between groundwater and sediments, biochemical reactions, and surface water-groundwater interactions, along with agriculture irrigation $[4,5]$ and other human activities [6-11]. Whether treated or not, industrial and municipal wastewaters are constant pollution sources that will pollute phreatic aquifer and then influence hydrochemistry of confined water $[4,5,9,11]$. And this may be especially serious in areas where groundwater was concentrated and exploited from deep aquifers, such as the study area [4]. Diverse phenomena such as mix pumping from several aquifers with different quality, heating and cooling water by ground-source heat pumps, underground storage of waste, injecting industrial effluents into aquifers, and the artificial recharge of aquifers (e.g., protecting depression cone in cities by groundwater injection well) [12] can be considered as point sources of pollution for deep aquifers. Additionally, shallow aquifers may be polluted by nonpoint sources, such as the infiltration of chemical fertilizers and pesticides used in agriculture via leaching into irrigation water $[4,5]$, and then leakage recharge deep aquifers as nonpoint sources in depression cones $[3,4]$. Such pollution sources and groundwater exploitation from deep aquifers will exert great influence over groundwater resources of 
deep aquifers by profoundly altering their hydrochemistry, causing many problems such as the deterioration of wetlands [13], land subsidence [14], seawater intrusion [15, 16], a decline in groundwater levels, and building damage [14]. Once a sediment aquifer deteriorated, the time and cost of restoration to its original condition may be excessive [15].

As studied in our former paper published in "Water" [4], confined water of the Yinchuan region of northwest China, existing in Quaternary loose sediment aquifers, is the main water source of industrial use and municipal drinking [4]. As the groundwater quality of phreatic aquifers has been deteriorated in general [4], so industrial and drinking needs in Yinchuan city seek for confined water since 1970s. And $\sim 8.7 \times 10^{7} \mathrm{~m}^{3} /$ a groundwater has been exploited in a concentrated manner from the confined aquifers by 212 wells, forming a depression cone in the vicinity of Ningxia University [4].

Given the confined aquifer's roof depth of 25-60 $\mathrm{m}$ and a relatively continuous clay layer that exists between the confined aquifer and phreatic aquifer across the whole region, the recharge of the confined aquifer therefore occurs mainly via groundwater runoff from boundaries of the study area and leakage recharge from phreatic aquifer in the depression cone [17]. So, the confined water is not easily polluted by the external environment, under typical conditions. However, widespread contamination has lowered the quality of phreatic water in irrigation farmland areas (just matching the study area), by domestic sewage (more than $6.0 \times 10^{7} \mathrm{~m}^{3}$ in 2011), industrial effluent (about $1.0 \times 10^{8} \mathrm{~m}^{3}$ in 2011), and chemical fertilizers in point sources and nonpoint sources [4]. The main causes of confined aquifers contamination are aquifer deterioration due to leakage recharge from phreatic aquifers in the depression cone and mixed pumping from several aquifers in some irrigation wells (including polluted phreatic aquifer and confined aquifer).

Along with the aforementioned factors, increased pumping of groundwater from the confined aquifer adds a fundamental pressure to groundwater quality and management. Over time, artificial perturbations of pumping (i.e., fluctuations in the rate and frequency) have greatly influenced the natural hydrochemical patterns of confined water in the Yinchuan region. Human interventions have also caused complicated spatial-temporal changes in the quantity and quality of confined water in the depression cone, giving rise to a unique artificial-natural ecosystem. These pressures make the dynamics of confined water hydrochemistry in the region relatively more complex.

As the hydrochemistry and influence factors of phreatic water have been discussed [4] and from the close connection of phreatic water and confined water in the study area, along with the given complexity, numerous studies can provide a comprehensive understanding of confined water hydrology, especially regarding the interactions between confined aquifers and phreatic aquifers. For instance, multivariate statistical techniques, such as principal component analysis (PCA), have been used widely in hydrogeological studies to reduce the complexity of large-scale data sets and thus identify relationships among numerous factors. Some studies have done so to analyze temporal changes in surface or groundwater characteristics [18-22], while others have used PCA to analyze the relationship between a pollutant and other physicochemical parameters [23] or to describe the characteristics of a given aquatic system [24-26].

So, in this context, in order to determine the composition and formation of confined water and the effect analysis of phreatic water on it, the hydrogeological processes involved in recharge, runoff, and discharge of sedimentary aquifer of the Yinchuan region have been analyzed by multifactorial statistical analysis and serve as a simple example to provide suggestion for the status change, evolution, and protection of groundwater ecological environment under groundwater concentrated exploitation in other arid/semiarid area. Such an approach can provide a means to explain the current status of groundwater variability, to determine the factors that influence the quality of confined water in Yinchuan, and then to develop sound groundwater management options to preserve the quantity and quality of water resources and avoid the undesirable impact of phreatic water on the confined aquifer. Our specific objectives were to (1) calculate saturation indices to analyze the dissolution/precipitation of minerals; (2) assess the chemical characteristics of confined water in order to identify factors that affect the region's confined water chemistry; (3) use PCA to identify the main drivers of confined water hydrochemistry; and (4) use correlation analysis to identify several relevant hydrochemical relationships.

\section{Study Area}

2.1. Location. The study area is located in the middle of the Yinchuan plain, northwest China. It measures $31 \sim 44 \mathrm{~km}$ wide from the front of Helan Mountain in the west to the Yellow River's western bank in the east and $38 \mathrm{~km}$ long from south to north, with a total area of $1555 \mathrm{~km}^{2}$ (Figure 1).

The Yinchuan region has an arid to semiarid climate within the north temperature zone, with long winters, short summers, low rainfall, frequent droughts, ample sunshine, high wind and evaporation, and dramatic temperature changes. According to monitoring data from 1951 to 2010, the mean annual precipitation is $191.9 \mathrm{~mm}$, with $70 \%$ of it concentrated from July to September, and the average annual evaporation is $1582.8 \mathrm{~mm}$, more than 8 times the amount of precipitation [27].

2.2. Hydrogeology. The study area's elevation is in the range of 1100 1150 $\mathrm{m}$ above mean sea level and is higher in the west and lower in the east. Landforms show a zonal distribution, sloping from the leaning pluvial plain at the foot of Helan Mountain in the west, to the pluvial-alluvial plain of the Yellow River and alluvial-lacustrine plain and alluvial flat in the east (Figure 1).

The Yinchuan plain was formed by deposition of river, lake, and flood sediments over a Cenozoic fault basin. It is a graben basin, based on evolution of the Helan tectonic belt that experienced numerous rising and sinking processes between the Mesoproterozoic and Cenozoic eras [17, 28]. The pore water aquifers can be divided into two main aquifer 


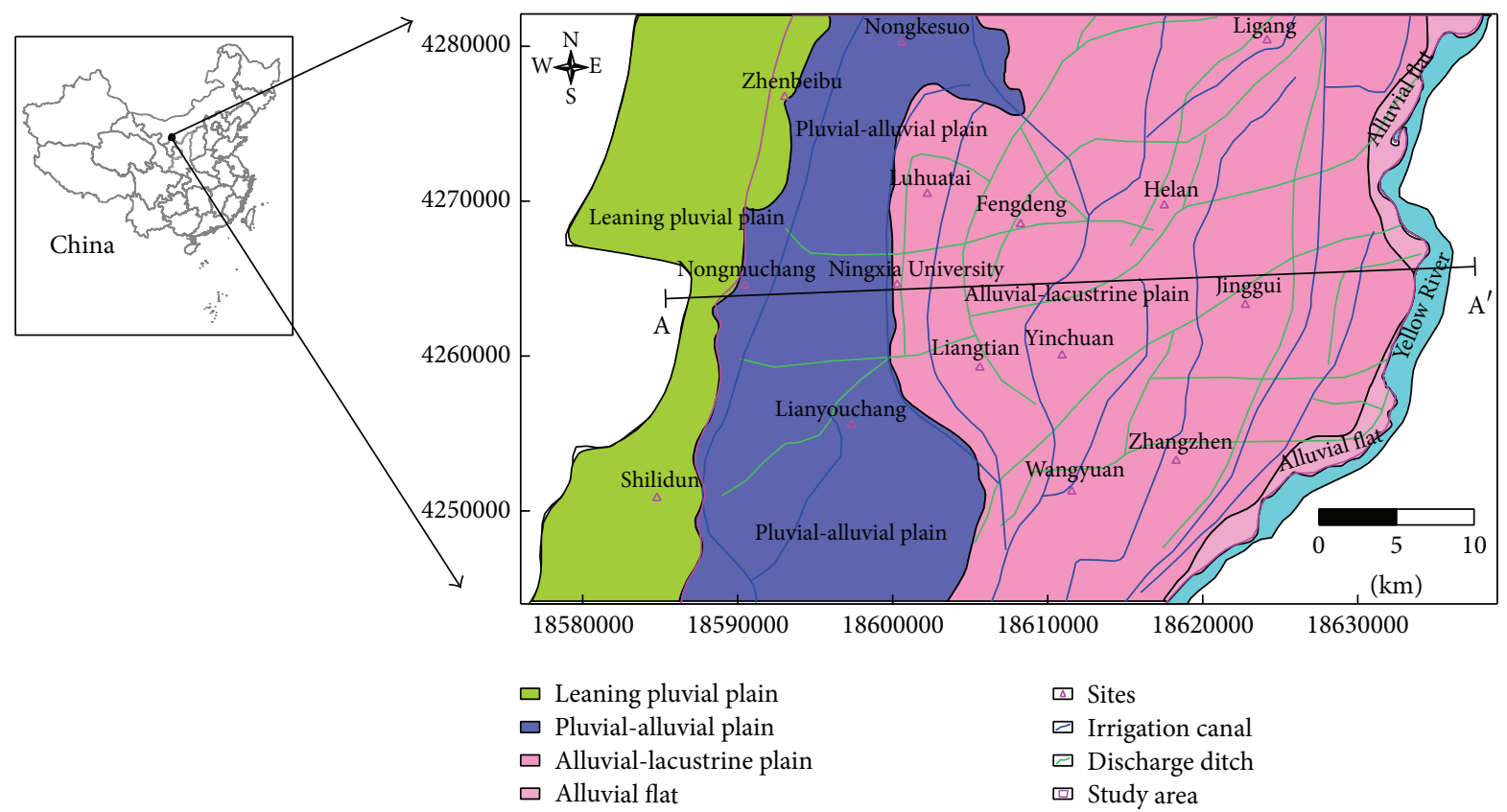

FIgURE 1: Location of the study area and landforms in Yinchuan, Ningxia Province, China, according to [4].

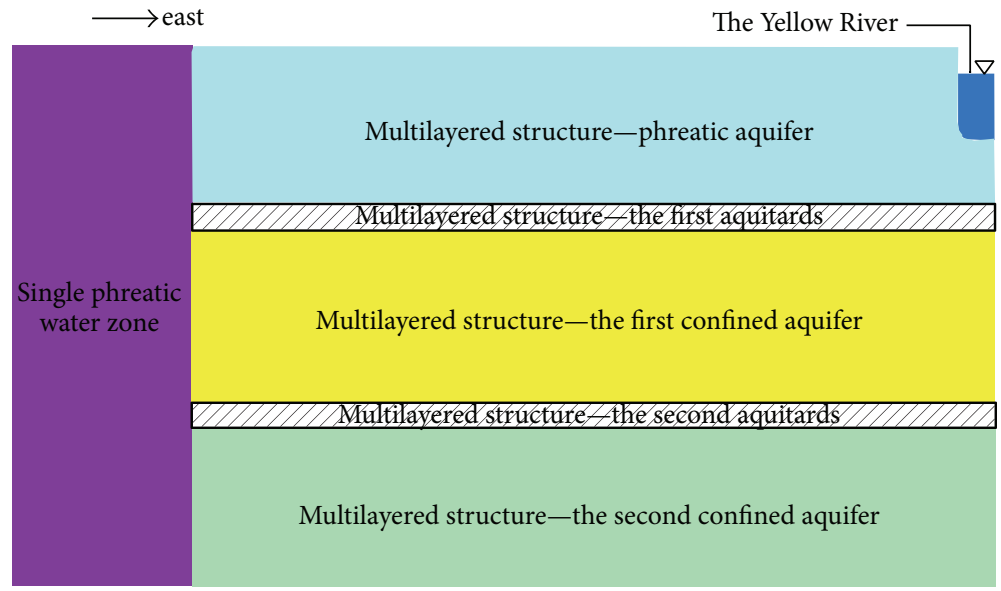

Figure 2: The conceptual scheme of hydrogeological cross section from A to $\mathrm{A}^{\prime}$.

systems: a single phreatic water zone and an area with a multilayered structure, that is, the study area [4] (Figure 2), characterized by three aquifer layers within a depth of $250 \mathrm{~m}$ : moving down from the surface they are phreatic aquifer, upper confined aquifer, and lower confined aquifer, and these aquifers are separated by nearly continuous, 3 10 m-thick, low permeability aquitards [17].

The hydrogeological research focuses on the relationship between the confined and phreatic aquifers. The distribution of groundwater levels of the confined water is consistent with topography, and groundwater flows mainly from west to east in nature (Figure 3), but the specific runoff directions and conditions vary somewhat across the region.

In order to supply the consumption of industrial and drinking water in Yinchuan city, a long-term, concentrated exploitation of groundwater (212 wells) from the confined aquifer has been implemented at the rate of $8.7 \times 10^{7} \mathrm{~m}^{3} / \mathrm{a}$ for more than 50 years [4], and a depression cone has formed in the area bounded by Luhuatai and Gaomiao in the north, Fengying village and Pingjibu in the south, the West Main Canal in the west, and Daxin town in the east, with an area of $412.37 \mathrm{~km}^{2}$ in 2011 . So, the lateral direction of groundwater flow changes greatly at the center of the depression cone, and the hydraulic gradient increases significantly, a range of $0.06 \%-5.1 \%$. As the groundwater level difference, phreatic water recharges the confined water in the vertical direction in a large amount about $9.1 \times 10^{7} \mathrm{~m}^{3} / \mathrm{a}$, while confined water supplies the phreatic aquifer in other areas in very small amount [4].

The roof depth of the confined aquifer is $\sim 25-60 \mathrm{~m}$, with a relatively continuous clay layer between the confined and phreatic aquifers in the study area with a typical thickness 


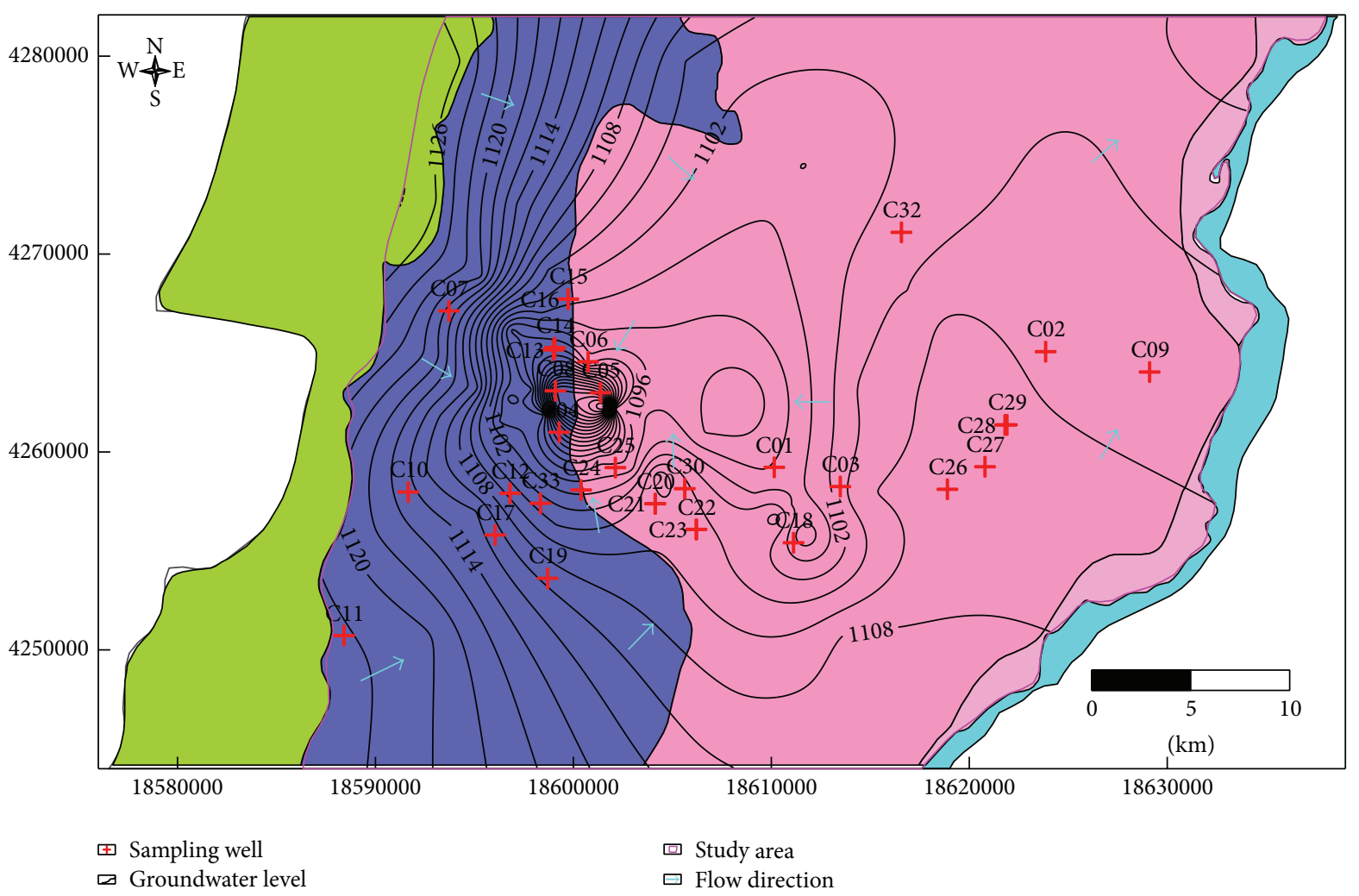

FIGURE 3: Hydrogeological map of confined aquifer and sampling wells in the study area (m).

of 3-10 $\mathrm{m}$ (maximum $50 \mathrm{~m}$ ) that decreases from west to east. Recharge of the confined aquifer therefore occurs mainly via leakage recharge by the phreatic aquifer in vertical direction and also runoff from the single phreatic water zone, at the boundary of confined aquifer with the single phreatic water zone in west $\left(\sim 3.6 \times 10^{7} \mathrm{~m}^{3} / \mathrm{a}\right)$ (Figure 3), accounting for $24 \%$ of the total recharge.

The main pollution source of confined water in the study area is the polluted phreatic aquifer, which has itself been contaminated seriously by industrial waste, sewage, pesticides, and fertilizers, infiltrating into groundwater [4]. These sources can be classified according to the three basic forms of groundwater pollution: point sources, nonpoint sources, and linear sources. Point source pollution refers mainly to industrial wastewater from factories, such as the Yinchuan chemical fertilizer plant and Helan paper mill. Another point source is agriculture, such as sewage ponds, garbage dumps, septic tanks, and fish ponds that use fertilizers. Key linear pollution sources are drainage ditches, accepting domestic sewage from families and industrial wastewater from mills. The important ditches in the region are the four-two main ditch, the 2nd and 4th drainage ditches, and the threeone branch ditch. Discharge of industrial effluent (about $1.0 \times 10^{8} \mathrm{~m}^{3}$ in 2011) and domestic sewage (more than 6.0 $\times 10^{7} \mathrm{~m}^{3}$ in 2011) through these channels flow into the Yellow River, polluting groundwater along the seepage path of unlined ditches in infiltrating manner. Nonpoint source pollution refers to the chemical fertilizers and toxic pesticides used in agriculture (about $5-10 \mathrm{~g} / \mathrm{m}^{2}$ ), which contaminated shallow groundwater indirectly (phreatic water in the study area) [4].

\section{Materials and Methods}

3.1. Sampling Locations and Analytical Procedures. Groundwater samples of confined aquifer were taken from 33 wells in 2011 , before the summer-autumn irrigation period. They were labeled with a 3-character code, $\mathrm{CAB}$, where $\mathrm{C}$ represents confined water and $\mathrm{AB}$ is the two-digit number of the sampling station (Figure 3). Physicochemical parameters such as $\mathrm{pH}$ and temperature were measured in situ. Sampling water was collected in precleaned $1 \mathrm{~L}$ plastic polyethylene bottles, after 3 times thorough rinse of the bottle with sampling water. Handling and preservation of samples followed the standard examination methods for drinking water to maximize quality and consistency [29]. We checked those measurements by calculating percent charge balance errors (\% CBE):

$$
\% \mathrm{CBE}=\frac{\sum \text { cations }-\sum \text { anions }}{\sum \text { cations }+\sum \text { anions }} \times 100 \% \text {, }
$$

where all cations and anions are expressed as milliequivalents/L. All samples had small relative errors (\% CBE) of $< \pm 5 \%$; therefore all 33 samples were used in analyses (see Supplementary Data in Supplementary Material available online at http://dx.doi.org/10.1155/2016/3812125).

3.2. Multivariate Statistical Analysis. Multivariate statistical techniques, such as PCA, can provide "unbiased methods" to 
TABLE 1: Descriptive statistics of hydrochemistry in Yinchuan, China.

\begin{tabular}{|c|c|c|c|c|c|c|c|}
\hline \multirow{2}{*}{$\begin{array}{l}\text { Parameters } \\
\text { Category }\end{array}$} & \multicolumn{5}{|c|}{ Confined water } & \multirow{2}{*}{$\begin{array}{c}\text { Phreatic water } \\
/\end{array}$} & \multirow{2}{*}{$\begin{array}{c}\text { National standard } \\
/\end{array}$} \\
\hline & Minimum & Maximum & Mean & $\mathrm{SD}$ & $\mathrm{CV}$ & & \\
\hline$\overline{\mathrm{pH}}$ & 8.06 & 8.43 & 8.21 & 0.16 & 0.02 & 7.57 & $6.5-8.5$ \\
\hline $\mathrm{TH}$ & 129 & 441 & 244 & 71 & 0.29 & 662 & 450 \\
\hline TDS & 307 & 799 & 472 & 162 & 0.34 & 889 & 1,000 \\
\hline $\mathrm{Ca}^{2+}$ & 11.5 & 94.1 & 44.4 & 19.8 & 0.45 & 111.5 & - \\
\hline $\mathrm{Mg}^{2+}$ & 5.8 & 73 & 37.1 & 13.4 & 0.36 & 107.0 & - \\
\hline $\mathrm{K}^{+}$ & 1.0 & 3.5 & 2.0 & 0.6 & 0.30 & 7.2 & - \\
\hline $\mathrm{Na}^{+}$ & 27.2 & 168 & 75 & 48 & 0.64 & 147.0 & 200 \\
\hline $\mathrm{Cl}^{-}$ & 19.9 & 258 & 67 & 58 & 0.87 & 138.0 & 250 \\
\hline $\mathrm{SO}_{4}{ }^{2-}$ & 17.7 & 175 & 84 & 45 & 0.54 & 294.0 & 250 \\
\hline $\mathrm{HCO}_{3}^{-}$ & 195 & 484 & 285 & 61 & 0.21 & - & - \\
\hline $\mathrm{NO}_{3}^{-}$ & 0.0 & 2 & 0.1 & 0.4 & 3.46 & 17.9 & 20 \\
\hline $\mathrm{NH}_{4}^{+}$ & 0.0 & 0.9 & 0.1 & 0.2 & 3.52 & 0.1 & 0.20 \\
\hline $\mathrm{F}^{-}$ & 0.1 & 0.7 & 0.2 & 0.1 & 0.66 & 1.3 & 1 \\
\hline
\end{tabular}

Units: $\mathrm{mg} / \mathrm{L}$ (except for $\mathrm{pH}$ ).

"Phreatic water" is the quality of phreatic water located in the central of the depression cone.

detect associations between samples and/or variables, using standardized data [30]. Such associations among physicochemical variables, based on similar magnitudes and variations in chemical and physical compositions, may reveal the effects of water-rock interaction, climate, and human activity on groundwater quality. In order to avoid misclassification of the water quality variables due to wide differences in the dimensions of sample data, we standardized measurements with a $z$-scale transformation $[18,31]$; this tends to increase the influence of main factors with small variance, and vice versa. All mathematical and statistical analyses were performed using the statistical software SPSS 16.0 [32]. The experimental $32 \times 12$ matrix was analyzed using PCA, and the resulting principal components (PCs) and varimax rotated PCs (VFs) were analyzed in detail.

\section{Results and Discussion}

4.1. Hydrochemical Characteristics. Analysis of the 13 hydrochemical variables of confined water in the study area is summarized in Table 1 . The groundwater samples were weakly alkaline, with a $\mathrm{pH}$ range of 8.06-8.43. There was no significant variation of major ions concentrations among samples, with variation coefficients varying from $0.21\left(\mathrm{HCO}_{3}{ }^{-}\right)$to $0.87\left(\mathrm{Cl}^{-}\right)$. For example, the concentration of TDS varied from 307 to $799 \mathrm{mg} / \mathrm{L}$ (mean $472 \mathrm{mg} / \mathrm{L}$ ). Samples with TDS $<500 \mathrm{mg} / \mathrm{L}$ were mainly from the western part of the region, the west of the Fengdeng-Yinchuan-Wangyuan band, while samples in the central and eastern parts usually had TDS of 500-1000 mg/L (Figure 4). Only one sample, C31 (the Helan paper mill), had abnormally excessive TDS for the study area, TDS $>1.5 \mathrm{~g} / \mathrm{L}$, indicating that it was polluted by domestic sewage and industrial wastewater, so it was removed from this research. Measures of all major ions did not exceed China's acceptable limits for groundwater quality [33], except for $\mathrm{Cl}^{-}(\mathrm{C} 31, \mathrm{C} 32)$ and $\mathrm{NH}_{4}^{+}(\mathrm{C} 03, \mathrm{C} 05, \mathrm{C} 30$, and $\mathrm{C} 31)$, indicating that these samples are potable. $\mathrm{TH}$ measured as
$\mathrm{CaCO}_{3}$ varied from 129 to $441 \mathrm{mg} / \mathrm{L}$ (mean $244 \mathrm{mg} / \mathrm{L}$ ) and 150 to $300 \mathrm{mg} / \mathrm{L}$ in most areas, indicating slightly hard water. Generally, the groundwater samples from the depression cone contained high $\mathrm{HCO}_{3}{ }^{-}$and smaller concentrations of all other ions, which were more abundant in other areas due to mineral dissolution and cation exchange along the paths of groundwater flow [34].

Piper trilinear diagrams are used to easily distinguish hydrochemical patterns among groundwater quality data [32, $34,35]$. In terms of cations, most samples fell in the central zone of the left delta-shaped region of our Piper diagram (Figure 5), suggesting that some stations had sodium-type water while most were mixed-type. For anions, most samples were located in the left zone of the lower right delta-shaped region, indicating the dominance of bicarbonate-type water, while some stations had mixed-type.

4.2. Correlation Analysis. The correlations among water quality variables (Table 2 ) can reveal several relevant hydrochemical relationships [32]. Measures of the major ions, except for $\mathrm{K}^{+}, \mathrm{HCO}_{3}{ }^{-}$, and $\mathrm{Mg}^{2+}$, were significantly and positively correlated with TDS. Concentrations of $\mathrm{Cl}^{-}, \mathrm{SO}_{4}{ }^{2-}$, and $\mathrm{Na}^{+}$were positively related with each other, with correlation coefficients $(r)$ ranging from 0.662 to 0.885 and the significant at the 0.01 level, implying there may be a common cause of increases in these ions. Similarly, concentrations of $\mathrm{Ca}^{2+}$ and $\mathrm{Mg}^{2+}$ were strongly and positively correlated with $\mathrm{TH}(r=$ 0.825 and 0.555 , resp., and the significant at the 0.01 level), as hardness is an approximate measure of $\mathrm{Ca}^{2+}$ and $\mathrm{Mg}^{2+}$, and concentrations of $\mathrm{Ca}^{2+}$ and $\mathrm{Mg}^{2+}$ were weakly and negatively correlated $(r=-0.012)$. TH was also strongly correlated with $\mathrm{SO}_{4}{ }^{2-}(r=0.562)$ and $\mathrm{HCO}_{3}{ }^{-}(r=0.756)$ by significant at the 0.01 level (Table 2), implying that $\mathrm{TH}$ includes both temporary and permanent hardness.

We found that $\mathrm{Na}^{+}$was positively, significantly correlated with $\mathrm{Cl}^{-}(r=0.885)$ by significant at the 0.01 level, indicating 
TABLE 2: Correlation matrix of the 13 physicochemical water parameters. The values are the correlation coefficients $(r)$.

\begin{tabular}{|c|c|c|c|c|c|c|c|c|c|c|c|c|c|}
\hline & $\mathrm{pH}$ & $\mathrm{TH}$ & TDS & $\mathrm{Ca}^{2+}$ & $\mathrm{Mg}^{2+}$ & $\mathrm{K}^{+}$ & $\mathrm{Na}^{+}$ & $\mathrm{Cl}^{-}$ & $\mathrm{SO}_{4}{ }^{2-}$ & $\mathrm{HCO}_{3}{ }^{-}$ & $\mathrm{NO}_{3}{ }^{-}$ & $\mathrm{NH}_{4}^{+}$ & $\mathrm{F}^{-}$ \\
\hline$\overline{\mathrm{pH}}$ & 1 & & & & & & & & & & & & \\
\hline $\mathrm{TH}$ & -0.277 & 1 & & & & & & & & & & & \\
\hline TDS & $-0.484^{* *}$ & $0.674^{* *}$ & 1 & & & & & & & & & & \\
\hline $\mathrm{Ca}^{2+}$ & $-0.372^{*}$ & $0.825^{* *}$ & $0.706^{* *}$ & 1 & & & & & & & & & \\
\hline $\mathrm{Mg}^{2+}$ & 0.058 & $0.555^{* *}$ & 0.153 & -0.012 & 1 & & & & & & & & \\
\hline $\mathrm{K}^{+}$ & -0.094 & $0.581^{* *}$ & 0.205 & $0.359^{*}$ & $0.500^{* *}$ & 1 & & & & & & & \\
\hline $\mathrm{Na}^{+}$ & $-0.459^{* *}$ & 0.259 & $0.883^{* *}$ & $0.461^{* *}$ & -0.222 & -0.119 & 1 & & & & & & \\
\hline $\mathrm{Cl}^{-}$ & $-0.463^{* *}$ & $0.438^{*}$ & $0.873^{* *}$ & $0.622^{* *}$ & -0.141 & 0.113 & $0.885^{* *}$ & 1 & & & & & \\
\hline $\mathrm{SO}_{4}{ }^{2-}$ & $-0.474^{* *}$ & $0.562^{* *}$ & $0.895^{* *}$ & $0.519^{* *}$ & 0.231 & 0.207 & $0.783^{* *}$ & $0.662^{* *}$ & 1 & & & & \\
\hline $\mathrm{HCO}_{3}{ }^{-}$ & -0.222 & $0.756^{* *}$ & $0.476^{* *}$ & $0.482^{* *}$ & $0.629^{* *}$ & 0.29 & 0.141 & 0.081 & $0.406^{*}$ & 1 & & & \\
\hline $\mathrm{NO}_{3}^{-}$ & -0.184 & -0.093 & -0.196 & -0.087 & -0.036 & 0.273 & -0.202 & -0.128 & -0.163 & -0.148 & 1 & & \\
\hline $\mathrm{NH}_{4}^{+}$ & -0.261 & 0.063 & 0.26 & 0.063 & 0.019 & -0.041 & 0.286 & $0.391^{*}$ & 0.244 & -0.187 & 0.012 & 1 & \\
\hline $\mathrm{F}^{-}$ & -0.114 & $-0.399^{*}$ & 0.188 & -0.093 & $0.57^{* *}$ & $-0.38^{*}$ & $0.509^{* *}$ & 0.236 & 0.237 & -0.257 & -0.208 & -0.013 & 1 \\
\hline
\end{tabular}

${ }^{* *}$ Correlation $=$ significant at the level 0.01 (2-tailed).

${ }^{*}$ Correlation $=$ significant at the level 0.05 (2-tailed).

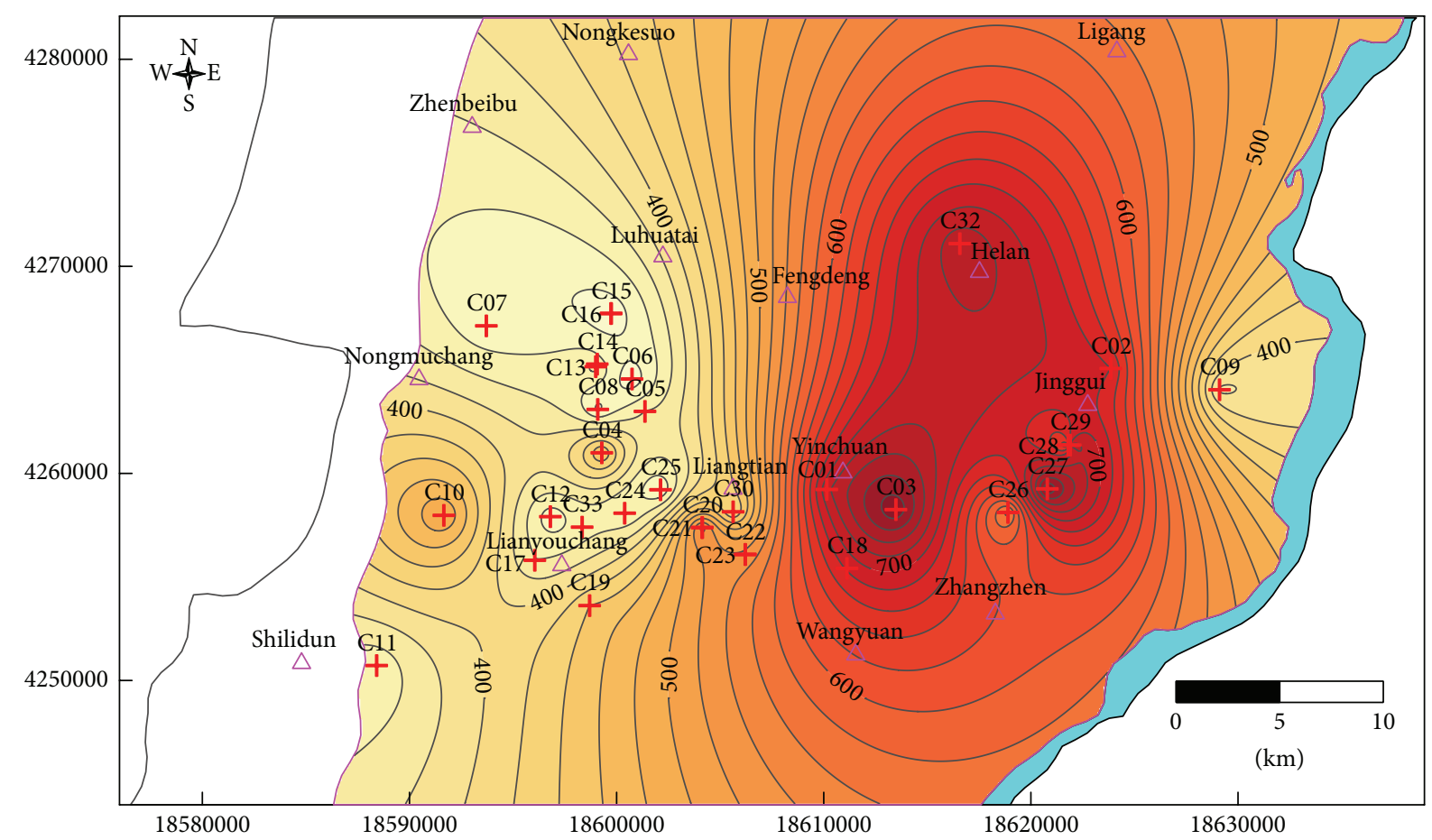

FIGURE 4: Spatial distribution of TDS of the study area $(\mathrm{mg} / \mathrm{L})$.

halite dissolution may be the major reaction influencing water chemistry of confined water in the study area. However, this finding is not consistent with the plots in Figure 6(a), as their concentrations were below the theoretical line $\left(\mathrm{Cl}^{-}\right.$ versus $\mathrm{Na}^{+}=1: 1$ expressed in $\left.\mathrm{mmol} / \mathrm{L}\right)$. Thus, the greater increase of $\mathrm{Na}^{+}$can be explained by the weathering of albite. The dissolution of albite can be expressed as follows:

$$
\begin{aligned}
& 2 \mathrm{NaAlSi}_{3} \mathrm{O}_{8}+2 \mathrm{H}_{2} \mathrm{CO}_{2}+9 \mathrm{H}_{2} \mathrm{O} \\
& \longrightarrow \mathrm{Al}_{2} \mathrm{Si}_{2} \mathrm{O}_{5}(\mathrm{OH})_{4}+2 \mathrm{Na}^{+}+2 \mathrm{HCO}_{3}{ }^{-} \\
& \quad+4 \mathrm{H}_{2} \mathrm{SiO}_{4}{ }^{2-}
\end{aligned}
$$

In addition, the ratios of $\mathrm{HCO}_{3}{ }^{-}$and $\mathrm{Ca}^{2+}$ in most samples were larger than two (Figure 6(b)), indicating that the effect of calcite dissolution on water chemistry is not obvious, and $\mathrm{HCO}_{3}{ }^{-}$comes from other sources, such as albite dissolution and ion exchange. The ion exchange can be expressed as follows: $\mathrm{Ca}^{2+}$ ions in solution were replaced with $\mathrm{Na}^{+}$from the solid surface, resulting in the deviation of $\mathrm{Ca}^{2+}$ out of the theoretical range (Figure 6(b)) and the surplus of $\mathrm{Na}^{+}$(Figure 6(a)). Consider the following:

$$
\mathrm{Ca}^{2+}+2 \mathrm{NaX} \longleftrightarrow 2 \mathrm{Na}^{+}+\mathrm{CaX}_{2}
$$

On the contrary, $\mathrm{HCO}_{3}{ }^{-}$is positively correlated with $\mathrm{Mg}^{2+}(r=0.629)$ and less correlated with $\mathrm{Ca}^{2+}$ 


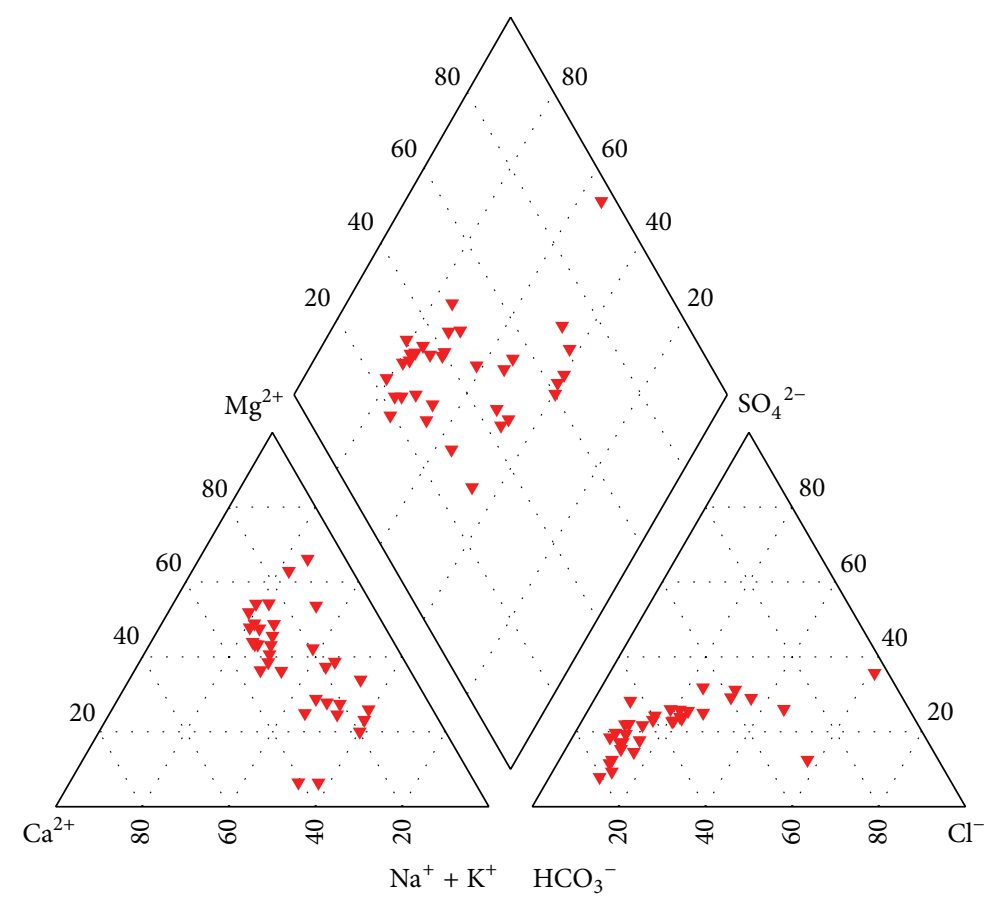

Figure 5: Piper diagram of confined water drawn with AquaChem 4.0.

$(r=0.482)$, both with the significant at the 0.01 level (Table 2). In addition, $\mathrm{Mg}^{2+}$ is weak negatively correlated with $\mathrm{Ca}^{2+}(r=-0.012)$, which suggests the possibility of dissolution and/or precipitation of calcite and dolomite. Hypothetically speaking, if calcite and dolomite dissolution were the only source of $\mathrm{Ca}^{2+}$ and $\mathrm{Mg}^{2+}$, the ratio between $\mathrm{HCO}_{3}{ }^{-}$and $\mathrm{Ca}^{2+}, \mathrm{Mg}^{2+}$ should be within the range of $1: 1$ to $2: 1$, depending on the amount of $\mathrm{CO}_{2}$ involved in the reactions [36], because

$$
\begin{aligned}
& \mathrm{CaCO}_{3}+\mathrm{H}^{+} \longleftrightarrow \mathrm{Ca}^{2+}+\mathrm{HCO}_{3}^{-} \\
& \mathrm{CaCO}_{3}+\mathrm{H}_{2} \mathrm{O}+\mathrm{CO}_{2} \longleftrightarrow \mathrm{Ca}^{2+}+2 \mathrm{HCO}_{3}^{-} \\
& \mathrm{CaMg}\left(\mathrm{CO}_{3}\right)_{2}+2 \mathrm{H}^{+} \longleftrightarrow \mathrm{Ca}^{2+}+\mathrm{Mg}^{2+}+2 \mathrm{HCO}_{3}^{-} \\
& \mathrm{CaMg}\left(\mathrm{CO}_{3}\right)_{2}+2 \mathrm{H}_{2} \mathrm{O}+\mathrm{CO}_{2} \\
& \longleftrightarrow \mathrm{Ca}^{2+}+\mathrm{Mg}^{2+}+4 \mathrm{HCO}_{3}^{-}
\end{aligned}
$$

It is suggested that dolomite dissolution is probably the source of $\mathrm{Mg}^{2+}$ and $\mathrm{Ca}^{2+}$ (Figure 6(c)) since some samples are within the hypothetical range $\left(\mathrm{HCO}_{3}{ }^{-}\right.$versus $\left(\mathrm{Ca}^{2+}+\right.$ $\left.\mathrm{Mg}^{2+}\right)=1: 1$ to $2: 1$ expressed in $\left.\mathrm{mmol} / \mathrm{L}\right)$ and some are above the hypothetical straight lines $\left(\mathrm{HCO}_{3}{ }^{-}\right.$versus $\left(\mathrm{Ca}^{2+}+\right.$ $\left.\mathrm{Mg}^{2+}\right)=1: 1$, meaning some $\mathrm{Ca}^{2+}$ or $\mathrm{Mg}^{2+}$ ions may have resulted from other causes. From comprehensive analysis of Figures 6(b) and 6(c), the superfluous ion is mainly $\mathrm{Mg}^{2+}$, coming from the dissolution of metamorphic rock (containing $\mathrm{Mg}^{2+}$ ), such as brucite and montmorillonite.

$\mathrm{Ca}^{2+}$ is also correlated with $\mathrm{SO}_{4}{ }^{2-}(r=0.592)$ by significant at the 0.01 level, suggesting a possible effect of gypsum dissolution on water chemistry. Consider the following:

$$
\mathrm{CaSO}_{4} \cdot 2 \mathrm{H}_{2} \mathrm{O} \longleftrightarrow \mathrm{Ca}^{2+}+\mathrm{SO}_{4}{ }^{2-}+2 \mathrm{H}_{2} \mathrm{O}
$$

However, the actual ratio between $\mathrm{Ca}^{2+}$ and $\mathrm{SO}_{4}{ }^{2-}$ is not $1: 1$. Considering the dissolution of calcite and/or dolomite that would introduce $\mathrm{Ca}^{2+}$ into groundwater, it is logical to conclude that the deviation of plotted data from the $1: 1$ line (below the hypothetical 1:1 line) was caused by the weathering of calcium-containing minerals, such as calcite and dolomite. Some samples fell above the hypothetical 1:1 line, suggesting the cation exchange between $\mathrm{Ca}^{2+}$ and $\mathrm{Na}^{+}$ (Figure 6(d)).

Notably, the chemical reactions within a groundwater system are numerous and highly complex. So assessment of the exact reactions taking place demands more comprehensive analyses of aquifer mineralogy and groundwater flow.

4.3. Major Ion Variation along Paths of Groundwater Flow. Physiochemical parameters for sample points along flow path can reveal changes in solutes that occur over time and travel distance [37]. The regional evolutionary trend of the predominant anions along the groundwater flow path can be summarized as follows: $\mathrm{HCO}_{3}{ }^{-} \rightarrow \mathrm{HCO}_{3}^{-}+$ $\mathrm{SO}_{4}{ }^{2-} \rightarrow \mathrm{SO}_{4}{ }^{2-}+\mathrm{HCO}_{3}{ }^{-} \rightarrow \mathrm{SO}_{4}{ }^{2-}+\mathrm{Cl}^{-} \rightarrow \mathrm{Cl}^{-}+$ $\mathrm{SO}_{4}^{2-} \rightarrow \mathrm{Cl}^{-}[34,38]$. As groundwater flows from the upper to lower reaches, concentrations of $\mathrm{Ca}^{2+}$ and $\mathrm{HCO}_{3}{ }^{-}$tend to decrease, while those of $\mathrm{Na}^{+}, \mathrm{K}^{+}, \mathrm{Mg}^{2+}, \mathrm{SO}_{4}{ }^{2-}$, and $\mathrm{Cl}^{-}$ increase [35]. There are two different patterns of groundwater evolution in the study area. Figure 7(a) illustrates the normal groundwater evolution along a flow path (from C11 to C19). 


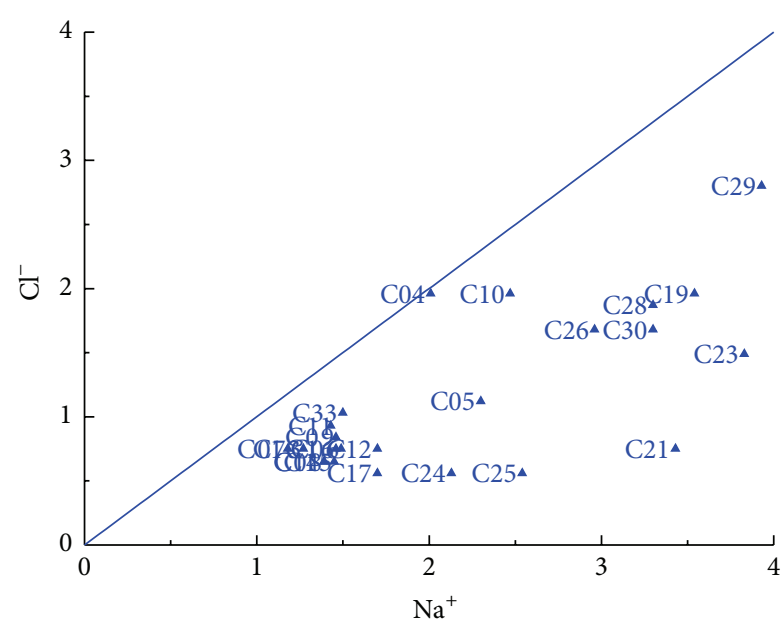

(a)

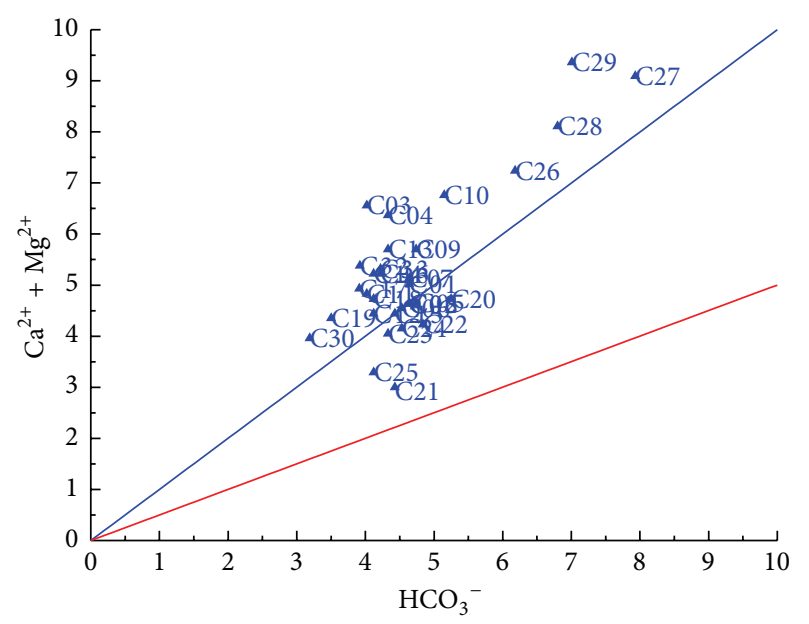

(c)

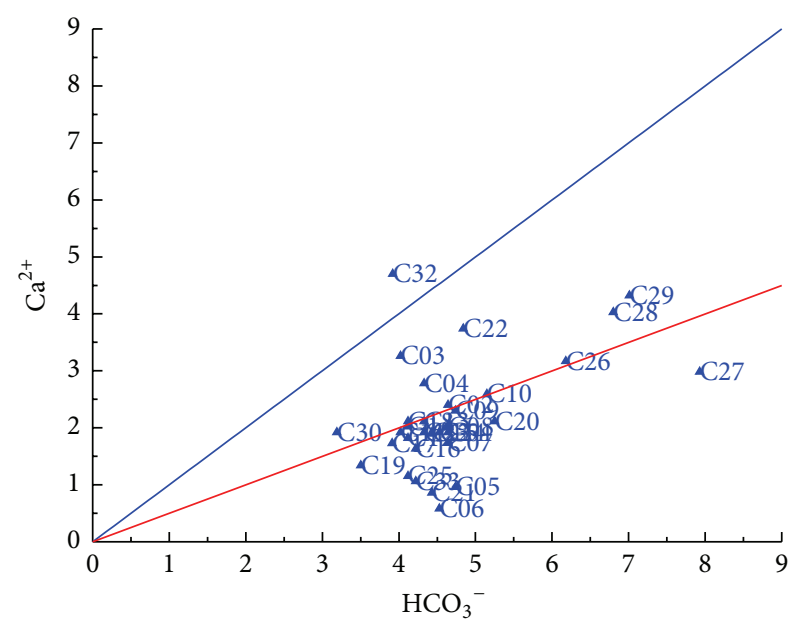

(b)

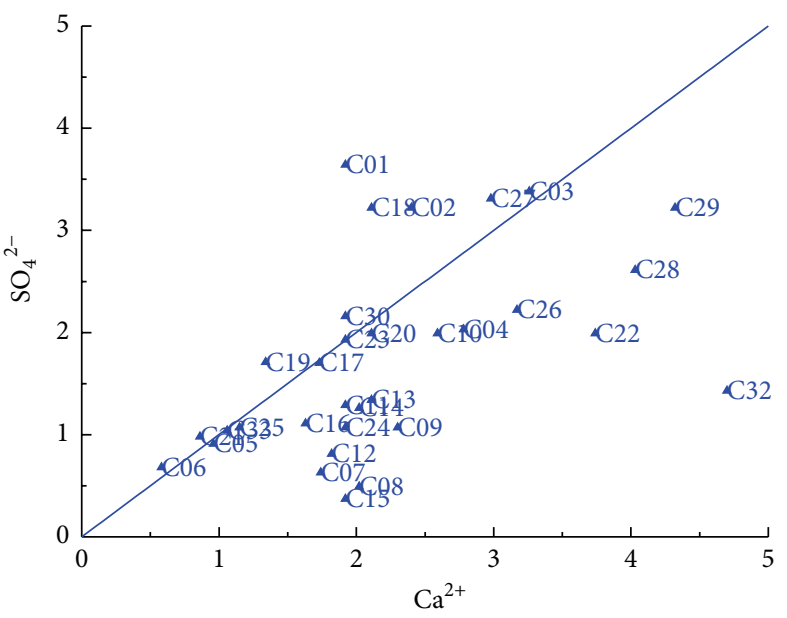

(d)

Figure 6: Plots of (a) $\mathrm{Na}^{+}$versus $\mathrm{Cl}^{-}$, (b) $\mathrm{Ca}^{2+}$ against $\mathrm{HCO}_{3}{ }^{-}$, (c) $\mathrm{Ca}^{2+}+\mathrm{Mg}^{2+}$ against $\mathrm{HCO}_{3}{ }^{-}$, and (d) $\mathrm{Ca}^{2+}$ versus $\mathrm{SO}_{4}{ }^{2-}$ (mmol/L).

Concentrations of $\mathrm{Na}^{+}, \mathrm{K}^{+}, \mathrm{Mg}^{2+}, \mathrm{Cl}^{-}$, and $\mathrm{SO}_{4}{ }^{2-}$ increased down the gradient, while $\mathrm{Ca}^{2+}$ and $\mathrm{HCO}_{3}{ }^{-}$decreased from 38.4 to $26.9 \mathrm{mg} / \mathrm{L}$ and from 245.1 to $212.7 \mathrm{mg} / \mathrm{L}$, respectively, resulting in the transition of hydrochemical type from $\mathrm{HCO}_{3}$ $\mathrm{Mg} \cdot \mathrm{Ca}$ to $\mathrm{HCO}_{3}-\mathrm{Na} \cdot \mathrm{Mg}$. However, the groundwater pattern may be different if there is local recharge of the phreatic aquifer along the flow path. Along the flow path from $\mathrm{C} 07$ to $\mathrm{C} 08, \mathrm{Mg}^{2+}, \mathrm{SO}_{4}{ }^{2-}$, and $\mathrm{Cl}^{-}$decreased significantly, whereas $\mathrm{Na}^{+}, \mathrm{K}^{+}$, and $\mathrm{Ca}^{2+}$ increased considerably, and $\mathrm{HCO}_{3}{ }^{-}$ remained relatively constant (Figure $7(\mathrm{~b})$ ). The second pattern of groundwater evolution indicates that recharge water with relative low concentrations of dissolved $\mathrm{Mg}^{2+}, \mathrm{SO}_{4}{ }^{2-}$, and $\mathrm{Cl}^{-}$(due to the adsorption of continuous, 3-10 $\mathrm{m}$ thick aquitards, composed of clay and sand clay) could be mixed with confined water before reaching sample well C08, and ion exchange takes a notable role in this evolution. Also, the hydrochemical type changed from $\mathrm{HCO}_{3}-\mathrm{Mg}$. Ca to $\mathrm{HCO}_{3}$ $\mathrm{Na} \cdot \mathrm{Mg}$. The existence of two different groundwater evolution patterns shows that groundwater quality in the study area is influenced by regional groundwater flow and local recharge.
4.4. Saturation Indices. Due to the short contact time with the aquifer minerals and/or insufficient mineral sources, groundwater in recharge areas or those with a falling regional flow is not usually saturated with calcite, dolomite, and gypsum, while groundwater in discharge areas or those with a rising flow may become saturated with these minerals. The saturation index (SI) of calcite, dolomite, halite, and gypsum for each sample was calculated using the following equation [39]:

$$
\mathrm{SI}=\log \frac{\mathrm{IAP}}{K},
$$

where IAP is ion activity product in a mineral dissolution reaction, while $K$ is representative of the equilibrium constant of mineral dissolution at the active temperature (this time takes $10^{\circ} \mathrm{C}$, the average temperature for the study area). The SI of gypsum and halite varied from -2.23 to -0.84 and from -7.27 to -6.25 , respectively (Figures $8(a)$ and $8(b)$ ), suggesting that the groundwater would tend to dissolve gypsum and halite. However, the SI of calcite and dolomite ranged from 
TABLE 3: Schoeller index values of all samples.

\begin{tabular}{lcccccccc}
\hline Sample number & C01 & C02 & C03 & C04 & C05 & C06 & C07 & C08 \\
\hline CAI-I & -0.92 & -0.94 & -0.20 & -0.06 & -1.09 & -1.06 & -0.65 & -1.21 \\
CAI-II & -0.43 & -0.43 & -0.16 & -0.02 & -0.22 & -0.15 & -0.09 & -0.15 \\
\hline Sample number & C09 & C10 & C11 & C12 & C13 & C14 & C15 \\
\hline CAI-I & -0.82 & -0.31 & -0.62 & -1.35 & -0.78 & -1.21 & -1.30 & -1.01 \\
CAI-II & -0.11 & -0.08 & -0.11 & -0.19 & -0.10 & -0.14 & -0.16 & -0.13 \\
\hline Sample number & C17 & C18 & C19 & C20 & C21 & C22 & C23 & C24 \\
\hline CAI-I & -2.14 & -0.68 & -0.84 & -1.62 & -3.64 & -1.33 & -1.60 & -2.85 \\
CAI-II & -0.21 & -0.39 & -0.28 & -0.42 & -0.48 & -0.40 & -0.38 & -0.28 \\
\hline Sample number & C25 & C26 & C27 & C28 & C29 & C30 & C32 & C33 \\
\hline CAI-I & -3.58 & -0.78 & -0.74 & -0.80 & -0.44 & -1.00 & -0.01 & -0.51 \\
CAI-II & -0.39 & -0.16 & -0.21 & -0.16 & -0.12 & -0.31 & -0.02 & -0.09 \\
\hline
\end{tabular}

0.28 to 1.28 and from 2.01 to 3.39 , respectively, indicating that the groundwater is in balance to be oversaturated with the calcite and oversaturated with the dolomite (Figures 8(c) and $8(d))$.

4.4.1. Cation Exchange. Cation exchange is a process that commonly modifies the major ion chemistry of groundwater [40] and significantly influences the evolution of hydrochemical compositions $[41,42]$. It can be studied through chloroalkaline indices proposed by Schoeller [41-43]. The Schoeller indices such as CAI-I and CAI-II are calculated using the following formulas:

$$
\begin{aligned}
\text { CAI-I } & =\frac{\mathrm{Cl}^{-}-\left(\mathrm{Na}^{+}+\mathrm{K}^{+}\right)}{\mathrm{Cl}^{-}} \\
\text {CAI-II } & =\frac{\mathrm{Cl}^{-}-\left(\mathrm{Na}^{+}+\mathrm{K}^{+}\right)}{\mathrm{HCO}_{3}{ }^{-}+\mathrm{SO}_{4}{ }^{2-}+\mathrm{CO}_{3}{ }^{2-}+\mathrm{NO}_{3}{ }^{-}}
\end{aligned}
$$

where all ions are expressed in meq/L. If the indices were negative values, this may indicate that $\mathrm{Ca}^{2+}$ and $\mathrm{Mg}^{2+}$ have been removed from solution and $\mathrm{Na}^{+}$and/or $\mathrm{K}^{+}$have taken their place. Since the indices are positive, the inverse reactions have taken place. All of these samples had negative Schoeller index values (Table 3 ), showing that $\mathrm{Ca}^{2+}$ and $\mathrm{Mg}^{2+}$ had been removed from solution and $\mathrm{Na}^{+}$and/or $\mathrm{K}^{+}$had taken their place in all samples.

4.5. Principal Component Analysis (PCA). Bartlett's sphericity test confirmed that the 12 variables were not orthogonal, but rather correlated (Bartlett $\chi^{2}=877,66 \mathrm{df}, P \leq 0.001$ ). This enables explanation of the variation in these hydrochemical data using a lower number of variables. Additionally, the Kaiser-Meyer-Olkin method (KMO) showed that the measure of sampling adequacy (MSA) was 0.52 , indicating that the degree of correlation among the variables and the appropriateness of factor analysis was moderate.

The variable $\mathrm{pH}$ varied little and was weakly correlated with the others $(r=-0.484$ to 0.058$)$, so it was eliminated from analysis. PCA considered the hydrochemical variables common to all 32 samples, including $\mathrm{TH}, \mathrm{TDS}, \mathrm{K}^{+}, \mathrm{Na}^{+}$, $\mathrm{Ca}^{2+}, \mathrm{Mg}^{2+}, \mathrm{HCO}_{3}{ }^{-}, \mathrm{SO}_{4}{ }^{2-}, \mathrm{Cl}^{-}, \mathrm{NH}_{4}{ }^{+}, \mathrm{NO}_{3}{ }^{-}$, and $\mathrm{F}^{-}$.
TABLE 4: Loadings of variables on 4 significant varifactors (VFs) of water quality measurements.

\begin{tabular}{lcccc}
\hline Variable & VF1 & VF2 & VF3 & VF4 \\
\hline $\mathrm{TDS}$ & $\mathbf{0 . 9 7}$ & 0.16 & -0.11 & 0.07 \\
$\mathrm{Cl}$ & $\mathbf{0 . 9 0}$ & -0.13 & 0.05 & 0.25 \\
$\mathrm{Na}$ & $\mathbf{0 . 9 0}$ & -0.29 & -0.20 & 0.15 \\
$\mathrm{SO}_{4}$ & $\mathbf{0 . 8 5}$ & 0.18 & -0.17 & 0.12 \\
$\mathrm{Ca}$ & $\mathbf{0 . 7 8}$ & 0.25 & 0.21 & -0.26 \\
$\mathrm{TH}$ & $\mathbf{0 . 6 2}$ & $\mathbf{0 . 7 3}$ & 0.11 & -0.15 \\
$\mathrm{HCO}_{3}$ & 0.36 & $\mathbf{0 . 7 1}$ & -0.23 & -0.36 \\
$\mathrm{~K}$ & 0.20 & $\mathbf{0 . 5 8}$ & 0.55 & -0.10 \\
$\mathrm{Mg}$ & -0.05 & $\mathbf{0 . 9 2}$ & -0.12 & 0.11 \\
$\mathrm{~F}$ & 0.29 & $-\mathbf{0 . 7 4}$ & -0.31 & -0.11 \\
$\mathrm{NO}_{3}$ & -0.14 & -0.05 & $\mathbf{0 . 8 5}$ & 0.06 \\
$\mathrm{NH}_{4}$ & 0.24 & 0.01 & 0.03 & $\mathbf{0 . 9 2}$ \\
\hline Eigenvalue & 4.60 & 2.99 & 1.33 & 1.20 \\
$\%$ of variance explained & 38.3 & 24.9 & 11.1 & 10.0 \\
\% cumulative variance & 38.3 & 63.2 & 74.3 & 84.3 \\
\hline
\end{tabular}

The correlation matrix of the 12 variables (i.e., standardized data) revealed several hydrochemical relationships relevant to interpretation of the primary factors influencing current water chemistry in the confined water $[41,42]$. To reduce the overlap between original variables in each PC, a varimax rotation was conducted [18]. The total variance explained by each VF, their loadings, and eigenvalues were shown in Table 4 . Based on the principle of eigenvalues $>1,4$ VFs were obtained, accounting for $84.3 \%$ of the total variance in the original data set (Table 4). The first two VFs explained most of the variance, at $40.6 \%$ and $24.6 \%$, respectively, while VF3 and VF4 explained $10.6 \%$ and $8.4 \%$.

VF1 was highly related to TDS, $\mathrm{Cl}^{-}, \mathrm{Na}^{+}, \mathrm{SO}_{4}{ }^{2-}, \mathrm{Ca}^{2+}$, and $\mathrm{TH}$, indicating that these variables may be influenced by a common cause, namely, mineral dissolution during groundwater flow. Major ions, such as $\mathrm{Na}^{+}, \mathrm{Ca}^{2+}, \mathrm{SO}_{4}{ }^{2-}$, and $\mathrm{Cl}^{-}$, are important components of minerals such as halite, gypsum, plagioclase, and mirabilite. With respect to the high values of 


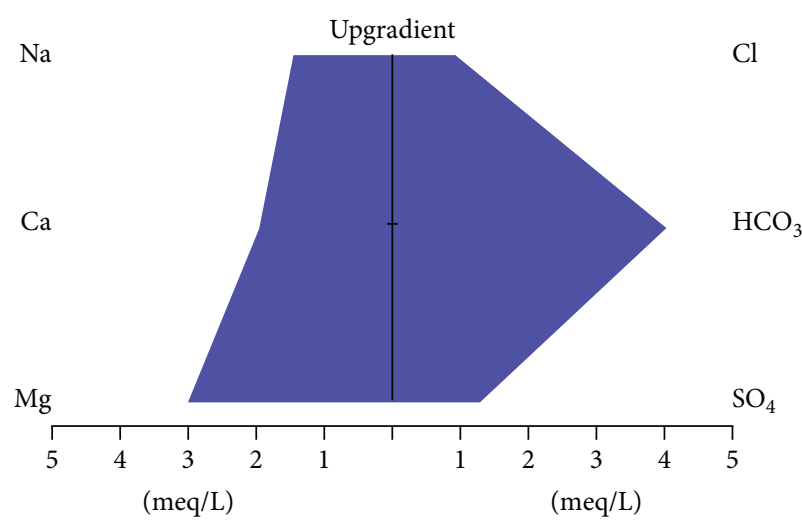

C11

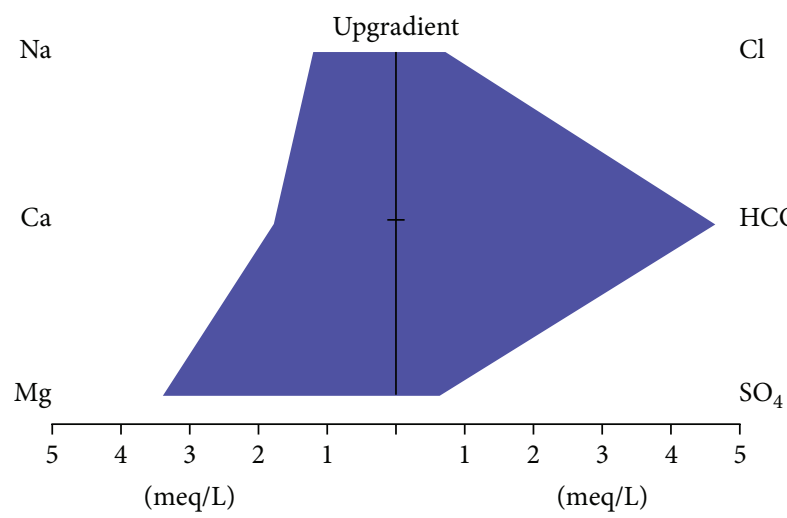

C07

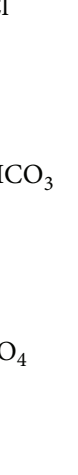

(a)

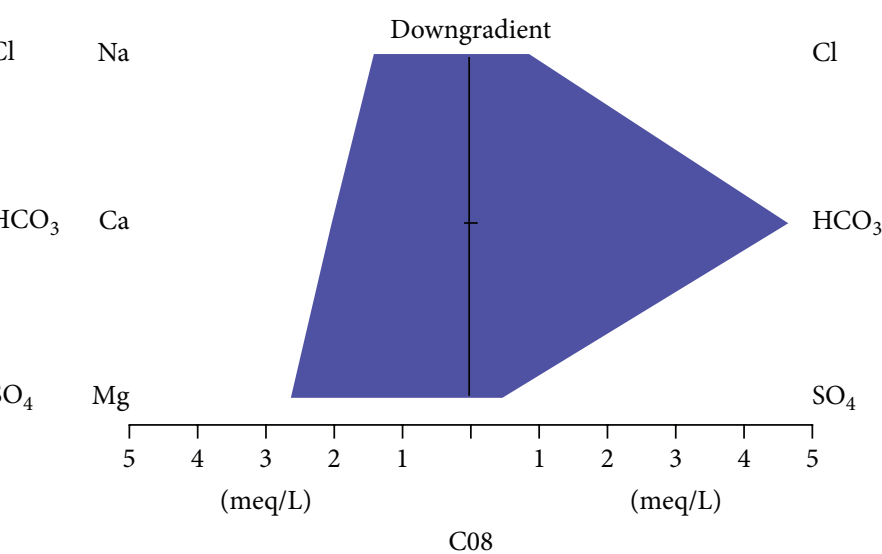

(b)

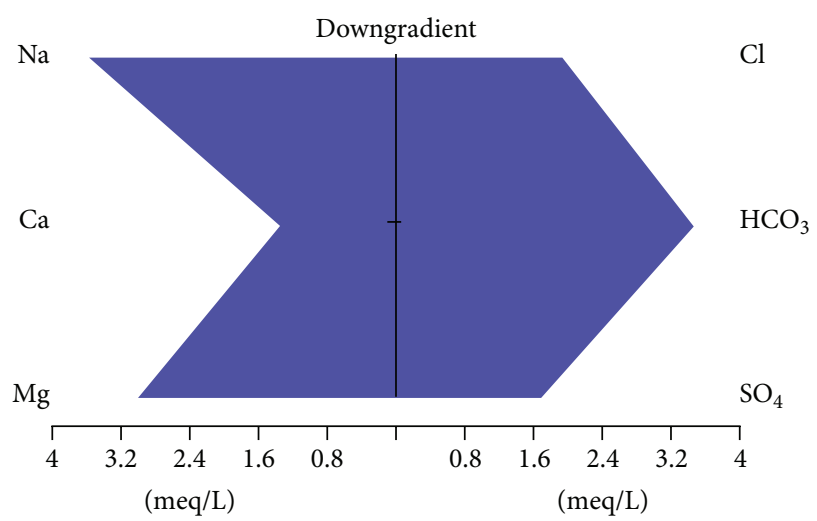

C19

Figure 7: Major ion variations along flow paths: (a) from C11 to C19; (b) from C07 to C08.

solubility product, $\mathrm{Na}^{+}, \mathrm{Ca}^{2+}, \mathrm{SO}_{4}{ }^{2-}$, and $\mathrm{Cl}^{-}$in the confined aquifer have dissolution tendency, and the concentrations of $\mathrm{Na}^{+}, \mathrm{Ca}^{2+}, \mathrm{SO}_{4}{ }^{2-}$, and $\mathrm{Cl}^{-}$have in turn increased. Based on particle analysis and the Quaternary sediment history of the study area, a very thick deposition of lake and alluvial facies filled the Yinchuan basin, including the minerals of quartz, halite, gypsum plagioclase, and mirabilite. Therefore, it is inferred that PC1 reflected the dissolution of minerals such as halite, gypsum, plagioclase, and mirabilite. Indeed, high values of VF1 were associated with the central and east parts of the study area, the lower reaches of groundwater flow (Figures 9(a) and 3).

Interestingly, VF1 values were lower in the central of the depression cone, where the hydraulic gradient is relatively large and phreatic water recharges confined water vertically to a great extent, so the concentrations of ions there should be relatively higher. Considering the adsorption of low permeability aquitards, the groundwater quality of confined water there is mainly affected by mineral dissolution and adsorption action, resulting in better quality [4].

Loadings on VF2 showed that $\mathrm{Mg}^{2+}, \mathrm{TH}, \mathrm{HCO}_{3}{ }^{-}, \mathrm{K}^{+}$, and $\mathrm{F}^{-}$were most important for VF2, representing dissolution of minerals (e.g., magnesite, dolomite, and potash feldspar) that contain $\mathrm{Mg}^{2+}, \mathrm{HCO}_{3}{ }^{-}$, and $\mathrm{K}^{+}$. In addition, the strongly negative correlation of $\mathrm{F}^{-}$with VF2 $(r=-0.74)$ indicated the potential precipitation of minerals (fluorite) containing $\mathrm{F}^{-}$and $\mathrm{Ca}^{2+}$. Sampling stations in the southwest (the finegrained zone) had high VF2 scores, but the scores of other area were relatively small. This suggests that there has been strong dissolution of minerals with $\mathrm{Mg}^{2+}, \mathrm{HCO}_{3}{ }^{-}$, and $\mathrm{K}^{-}$ in this area, with mixing action with phreatic water in the process (Figure $7(b)$ ). The spatial pattern of VF2 scores was different from that of VF1; that is, the distribution of high VF2 scores was concentrated in the southwest, where groundwater flows relatively slow and the dissolution of carbonate minerals is common (Figure 9(b)). In the central of the depression cone, considering the adsorption of low permeability aquitards, minerals precipitation (represented in Section 4.4), and the ion exchange, the groundwater quality of confined water will be better [4].

VF3 was greatly influenced by $\mathrm{NO}_{3}{ }^{-}$, as the mean $\mathrm{NO}_{3}{ }^{-}$ concentration of confined water in the study area is $0.1 \mathrm{mg} / \mathrm{L}$ (Table 1) and that of phreatic water is $2.1 \mathrm{mg} / \mathrm{L}$ [4]; it can be inferred to the mixing action between the confined aquifer and phreatic water polluted by nitrate fertilizers and the drainage ditch sewage used in agricultural irrigation [44]. Interestingly, small VF3 values were associated with the depression cone, indicating a low effect of nitrate pollution, 


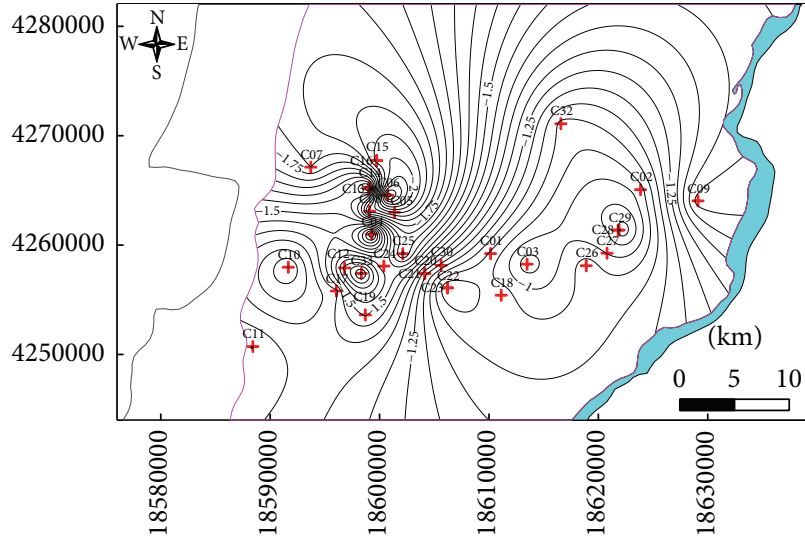

(a)

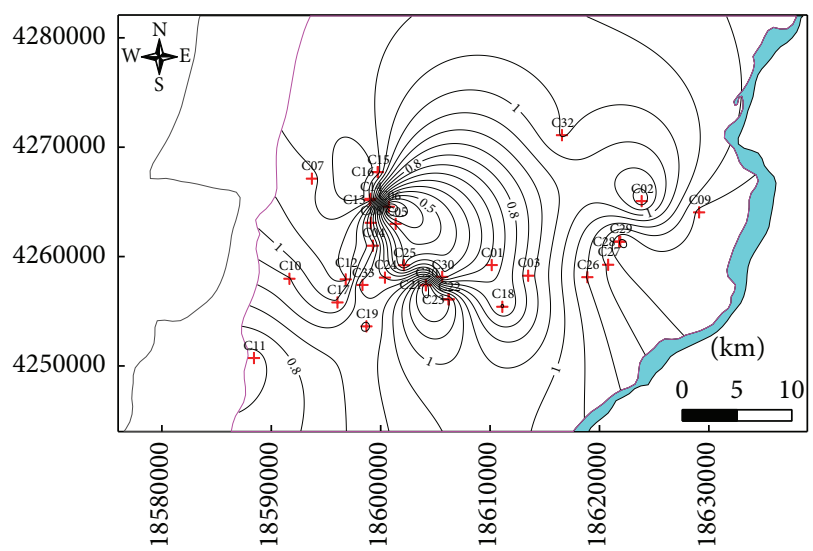

(c)

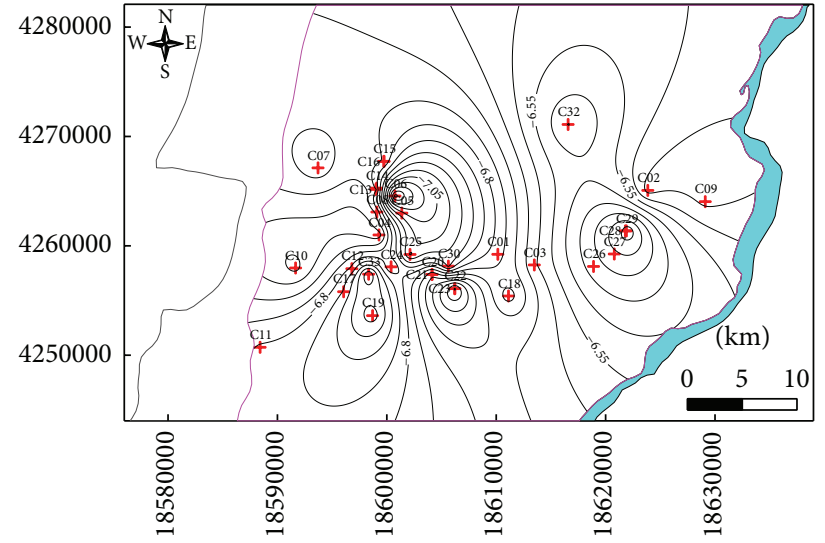

(b)

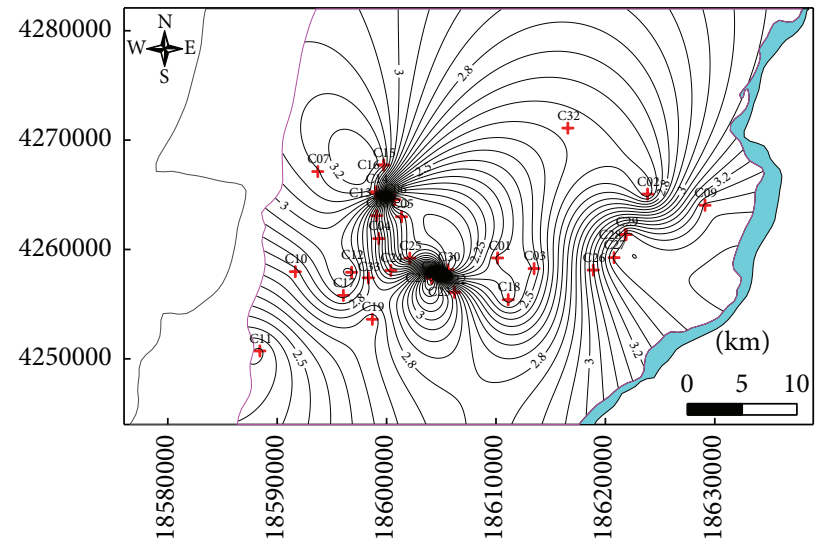

(d)

FIGURE 8: Saturation indices of minerals of confined water: (a) gypsum, (b) halite, (c) calcite, and (d) dolomite.

while high $\mathrm{NO}_{3}{ }^{-}$concentrations were located in the southwest (the fine-grained zone), because in the southwest area, there are some large farms, so phreatic water has high $\mathrm{NO}_{3}{ }^{-}$ concentrations and will flow into confined aquifer at the west boundary (Figure 2). The highest positive loading on VF4 was $\mathrm{NH}_{4}{ }^{+}$, implying an effect of human activity (e.g., domestic sewage discharge and agricultural fertilizers) on confined water from the polluted phreatic water.

4.6. The Comprehensive Analysis of the Aquifer System. In general, the quality of confined water in the study area was influenced mainly by mineral dissolution/precipitation, mixing action, and cation exchange, compared with phreatic aquifer by strong evaporation effect, mineral dissolution/ precipitation, and human activities [4]. Thus, the pollution risk of confined water in the study area is mainly the leakage recharge of polluted phreatic aquifer in the depression cone as continuous infiltration type [4]. Although the confined water has been exploited for more than 50 years and the groundwater quality is also very good (e.g., the concentration of TDS varied from 307 to $799 \mathrm{mg} / \mathrm{L}$, with a mean value of $472 \mathrm{mg} / \mathrm{L}$ ), however, the quality of confined water has been decreasing actually and confined aquifers will become contaminated because the aquitard layers can only provide a limited purifying effect. For example, for the typical sample C08 (Ningxia University), in the central of the depression cone, the concentration of TDS is $285 \mathrm{mg} / \mathrm{L}$ in $1990 \mathrm{~s}$ and that increased to $341 \mathrm{mg} / \mathrm{L}$ in $2000 \mathrm{~s}$. According to another researcher, in present exploitation condition, the concentration of $\mathrm{Cl}^{-}$in the first confined aquifer will increase clearly in the first 80 years (since 1970s), the increase will slow between 80 and 150 years, and the concentration then will become stable after 150 years, where there is excessive $\mathrm{Cl}^{-}$ (>250 mg/L) in the vicinity of Ningcheng village (the central of the depression cone), with an area of about $24.75 \mathrm{~km}^{2}$ [45]. According to the principle of adsorption, taking $\mathrm{Cl}^{-}$, for example, the adsorption capacity of low permeability aquitards in the depression cone was $2.22 \mathrm{mg} / \mathrm{kg}$ in 1991 and decreased insignificantly to $0.70 \mathrm{mg} / \mathrm{kg}$ in 2011 . It is obvious that the adsorption capacity has been reducing from 1991 to 2011 and the average adsorption amount of every five years also deceases from $100.1 \times 10^{5} \mathrm{~kg} /$ a to $59.1 \times 10^{5} \mathrm{~kg} / \mathrm{a}$, with the total adsorption amount of $1.76 \times 10^{8} \mathrm{~kg}$. The adsorption will take effect for no more than 150 a in this pumping condition, without taking any conversation measures.

In order to protect the groundwater quality in the study area and hence to ensure the long-term, sustainable levels of water extraction, regarding the phreatic aquifer and confined 


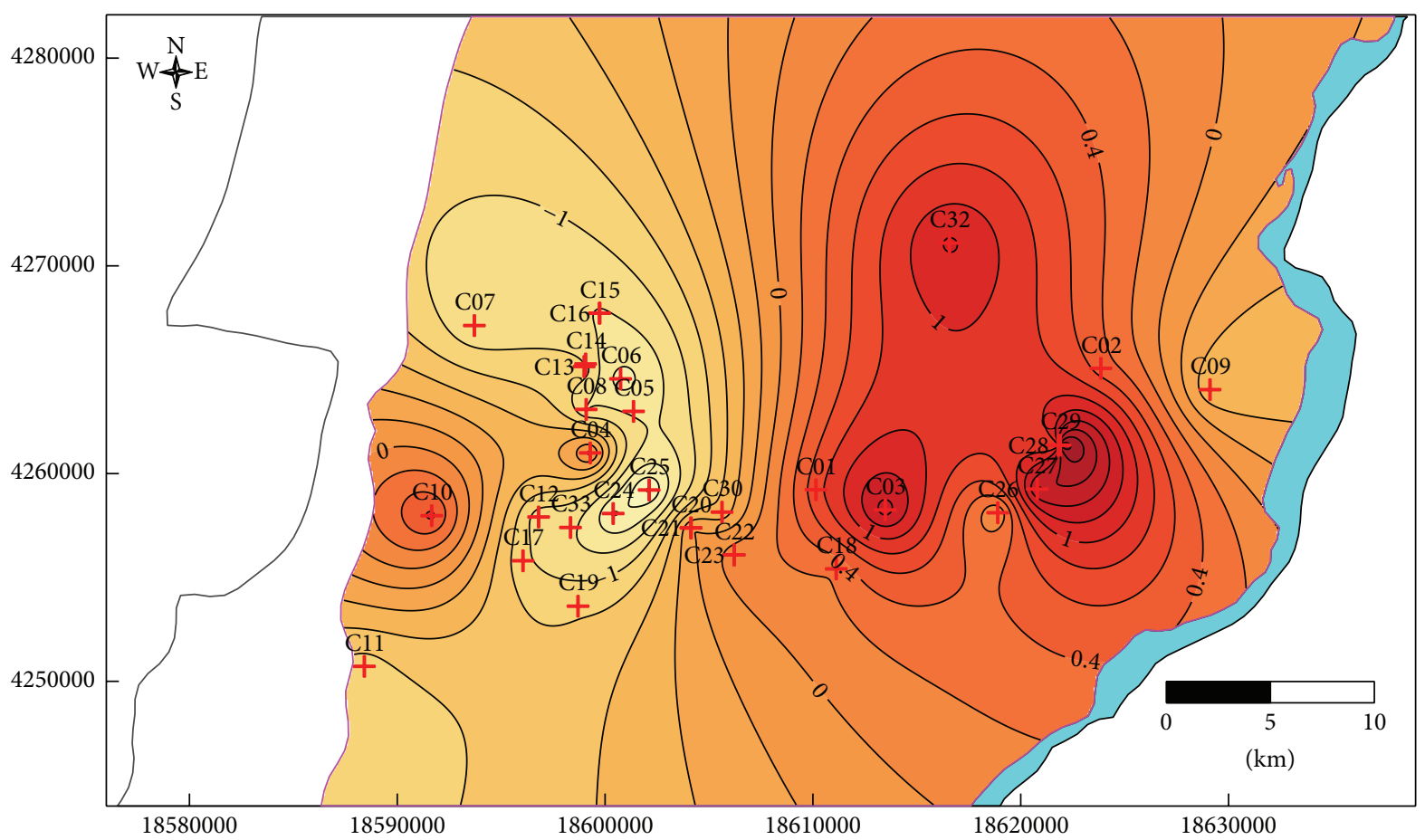

(a)

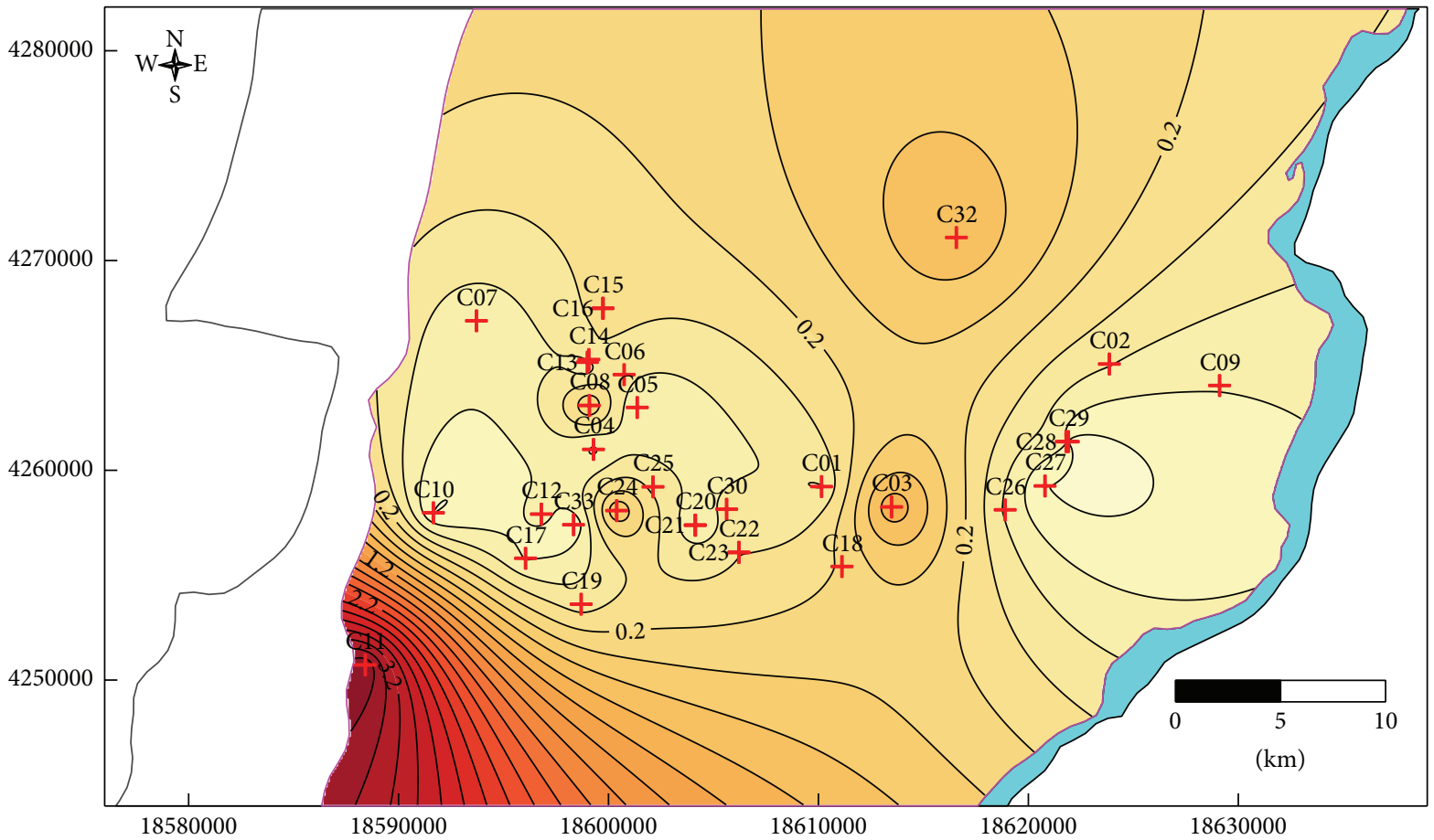

(b)

FIGURE 9: Spatial distribution of sampling stations by (a) VF1 scores and (b) VF2 scores.

aquifers as an entirety groundwater system, we recommend that the following management actions must therefore be undertaken: (1) Close enterprise wells of confined water gradually in the central of depression cone, only keeping on the drinking wells to reduce the exploitation intensity and well density. To meet demand, the Xixia reservoir has been constructed for these enterprises, which will save the pumping amount of $3.6 \times 10^{7} \mathrm{~m}^{3} / \mathrm{a}$ for confined water. (2) Do not increase the amount of confined water pumped from production wells and changing the exploitation rate by 
different times instead of the central one time, and additional water source sites and groundwater mining of confined aquifers should be planned in other places for future use. So two prospective areas of new groundwater source sites were delineated in the vicinity of Ligang and Zhangzhen town, with pumping guarantee of $8.0 \times 10^{4} \mathrm{~m}^{3} / \mathrm{d}$. (3) Establish several artificial recharge zones in the Helan leaning pluvial plain, using flood waters as the recharge water resources, about $5.5 \times 10^{7} \mathrm{~m}^{3} / \mathrm{a}$ for more than 52 gullies, to increase the groundwater recharge in the recharge area of confined water. (4) Improve the quality of phreatic water in the depression cone by sewage treatment plant, and the second, third, and fourth sewage treatment plants of Yinchuan have been constructed with the total treatment of $2.0 \times 10^{5} \mathrm{~m}^{3} / \mathrm{d}$ wastewater, covering more than $87.07 \mathrm{~km}^{2}$ and about $7.0 \times$ $10^{5}$ people, in which the third sewage treatment plant was built specially for industrial effluents in the depression cone. (5) Close and fill the wells mix pumping from phreatic aquifer and confined aquifers, protecting confined water from polluting, as the phreatic aquifer has bad quality.

From a management perspective and seen phreatic aquifer and confined aquifers as a whole system [4], our statistical analyses will be useful for hydrological planning - this approach avoids the undesirable location of new pumping wells in the confined aquifer at places that show hydrogeological or hydrochemical features associated with polluted phreatic aquifers and thus avoids and slows down further deterioration of groundwater quality. And this study will serve as a simple example to provide suggestion for the status change, evolution, and protection of groundwater ecological environment under groundwater concentrated exploitation in other arid/semiarid area.

\section{Conclusions}

Confined water is an invaluable resource that supports numerous activities in Yinchuan region, including industrial and domestic uses. However, its quality has been deteriorating gradually by leakage recharge from the polluted phreatic water. Although the Yinchuan region does not have significant limitations on the quantity of groundwater resources, entirety two distinct quality problems have been detected: phreatic water has high concentrations of major ions and TDS that exceed China's acceptable limits of groundwater quality, and polluted phreatic water recharges confined water largely in the depression cone, which will deteriorate confined water slowly. This paper investigated and assessed the hydrochemistry of major ions and trace constituents in confined water, using statistical methods and mineral dissolution/precipitation analysis, and the results can be summarized as follows:

(1) The quality of confined water varied slightly across the Yinchuan region and its composition was relatively simple, compared to that of phreatic water. TDS and concentrations of major ions generally increased along the groundwater flow path: from west to east. Measures of all major ions do not exceed China's acceptable limits for groundwater quality except for
$\mathrm{Cl}^{-}$and $\mathrm{NH}_{4}^{+}$in scattered areas, indicating the confined water is potable.

(2) The key factors affecting the evolution of groundwater chemistry of confined water in the study area are mineral dissolution and/or precipitation, cation exchange, leakage recharge, and human activity (e.g., domestic sewage discharge, agricultural fertilizers, and groundwater exploitation). Based on the saturation indices, the solubility products of calcite and dolomite were at supersaturation, with a precipitation tendency, and those of gypsum and halite were not saturated, so those minerals will dissolve into confined water. Because of the concentrated exploitation of confined water, a depression cone has been formed in the vicinity of Ningxia University, increasing leakage recharge to confined water, which will accelerate the evolution of groundwater chemistry in the confined aquifer.

(3) Multivariate analysis of confined water quality was used to identify different sources or processes that are influencing confined water quality as natural or human activities. Close examination of the four main axes that resulted from PCA identified three key processes that influence confined water quality in the region: the dissolution/precipitation of minerals including halite, gypsum plagioclase, mirabilite, magnesite, dolomite, potash feldspar, and fluorite; mixing between the confined water and polluted phreatic water; and effects of ion exchange.

(4) In order to exploit large amounts of confined water resources over long-term while avoiding its contamination by polluted phreatic water and improve the quality of the whole groundwater system, we recommend gradual close enterprise wells in the central depression cone, along with selectively exploiting phreatic water as an alternative to meet industrial water needs. Simultaneously, flood waters on the Helan leaning pluvial plain could be used to increase artificial recharge of the groundwater system.

\section{Competing Interests}

The authors declare that they have no competing interests.

\section{Acknowledgments}

This research was supported by the Doctor Postgraduate Technical Project of Changan University (2013G5290003) and the National Natural Science Foundation of China (41172212).

\section{References}

[1] R. Bowen, Ground Water, Applied Science Publishers, London, UK, 1980.

[2] M. E. Al-Ahmadi and A. A. El-Fiky, "Hydrochemical evaluation of shallow alluvial aquifer of Wadi Marwani, western Saudi 
Arabia," Journal of King Saud University-Science, vol. 21, no. 3, pp. 179-190, 2009.

[3] R. Q. Yuan, X. F. Song, D. M. Han, L. Zhang, and S. Q. Wang, "Upward recharge through groundwater depression cone in piedmont plain of North China Plain," Journal of Hydrology, vol. 500, pp. 1-11, 2013.

[4] X. D. Zhang, H. Qian, J. Chen, and L. Qiao, "Assessment of groundwater chemistry and status in a heavily used semi-arid region with multivariate statistical analysis," Water, vol. 6, no. 8, pp. 2212-2232, 2014.

[5] D. J. Qin, Y. P. Qian, L. F. Han, Z. M. Wang, C. Li, and Z. F. Zhao, "Assessing impact of irrigation water on groundwater recharge and quality in arid environment using CFCs, tritium and stable isotopes, in the Zhangye Basin, Northwest China," Journal of Hydrology, vol. 405, no. 1-2, pp. 194-208, 2011.

[6] B. Fridrich, D. Krčmar, B. Dalmacija et al., "Impact of wastewater from pig farm lagoons on the quality of local groundwater," Agricultural Water Management, vol. 135, pp. 40-53, 2014.

[7] S. Bartelt-Hunt, D. D. Snow, T. Damon-Powell, and D. Miesbach, "Occurrence of steroid hormones and antibiotics in shallow groundwater impacted by livestock waste control facilities," Journal of Contaminant Hydrology, vol. 123, no. 3-4, pp. 94-103, 2011.

[8] J.-C. Cho, H. B. Cho, and S.-J. Kim, "Heavy contamination of a subsurface aquifer and a stream by livestock wastewater in a stock farming area, Wonju, Korea," Environmental Pollution, vol. 109, no. 1, pp. 137-146, 2000.

[9] M. Kuderna and W. E. H. Blum, "N-fluxes and efficiencies on farms in Styria, Austria," Environmental Pollution, vol. 102, no. 1, pp. 507-513, 1998.

[10] A. Kunz, R. L. R. Steinmetz, M. A. Ramme, and A. Coldebella, "Effect of storage time on swine manure solid separation efficiency by screening," Bioresource Technology, vol. 100, no. 5, pp. 1815-1818, 2009.

[11] S. Lee, M. C. Maniquiz, and L.-H. Kim, "Characteristics of contaminants in water and sediment of a constructed wetland treating piggery wastewater effluent," Journal of Environmental Sciences, vol. 22, no. 6, pp. 940-945, 2010.

[12] S.-H. Moon, J.-Y. Lee, B.-J. Lee, K.-H. Park, and Y.-J. Jo, “Quality of harvested rainwater in artificial recharge site on Jeju volcanic island, Korea," Journal of Hydrology, vol. 414-415, pp. 268-277, 2012.

[13] A. A. L. Landes, L. Aquilina, J. De Ridder, L. Longuevergne, C. Pagé, and P. Goderniaux, "Investigating the respective impacts of groundwater exploitation and climate change on wetland extension over 150 years," Journal of Hydrology, vol. 509, pp. 367-378, 2014.

[14] C.-H. Chen, C.-H. Wang, Y.-J. Hsu, S.-B. Yu, and L.-C. Kuo, "Correlation between groundwater level and altitude variations in land subsidence area of the Choshuichi Alluvial Fan, Taiwan," Engineering Geology, vol. 115, no. 1-2, pp. 122-131, 2010.

[15] J. Bear, A. H. D. Cheng, S. Sorek, D. Ouazar, and I. Herrera, Seawater Intrusion in Coastal Aquifers-Concepts, Methods and Practices, Kluwer Academic Publishers, Dordrecht, The Netherlands, 1999.

[16] S. Onodera, M. Saito, M. Sawano et al., "Effects of intensive urbanization on the intrusion of shallow groundwater into deep groundwater: examples from Bangkok and Jakarta," Science of the Total Environment, vol. 404, no. 2-3, pp. 401-410, 2008.

[17] X. H. Wu, H. Qian, D. M. Yu et al., Investigation and Assessment of Rational Allocation of Groundwater Resources in the Yinchuan
Plain, Geology Publishing House, Beijing, China, 2008 (Chinese).

[18] B. Helena, R. Pardo, M. Vega, E. Barrado, J. M. Fernandez, and L. Fernandez, "Temporal evolution of groundwater composition in an alluvial aquifer (Pisuerga River, Spain) by principal component analysis," Water Research, vol. 34, no. 3, pp. 807-816, 2000.

[19] K. Bengraïne and T. F. Marhaba, "Using principal component analysis to monitor spatial and temporal changes in water quality," Journal of Hazardous Materials, vol. 100, no. 1-3, pp. 175-179, 2003.

[20] M. L. M. Jones, B. Reynolds, S. A. Brittain, D. A. Norris, P. M. Rhind, and R. E. Jones, "Complex hydrological controls on wet dune slacks: the importance of local variability," Science of the Total Environment, vol. 372, no. 1, pp. 266-277, 2006.

[21] D. Valdes, J.-P. Dupont, B. Laignel, S. Ogier, T. Leboulanger, and B. J. Mahler, "A spatial analysis of structural controls on Karst groundwater geochemistry at a regional scale," Journal of Hydrology, vol. 340, no. 3-4, pp. 244-255, 2007.

[22] F. Akbal, L. Gürel, T. Bahadir, I. Güler, G. Bakan, and H. Büyükgüngör, "Water and sediment quality assessment in the mid-Black Sea coast of Turkey using multivariate statistical techniques," Environmental Earth Sciences, vol. 64, no. 5, pp. 1387-1395, 2011.

[23] M. A. Halim, R. K. Majumder, S. A. Nessa, K. Oda, Y. Hiroshiro, and $\mathrm{K}$. Jinno, "Arsenic in shallow aquifer in the eastern region of Bangladesh: insights from principal component analysis of groundwater compositions," Environmental Monitoring and Assessment, vol. 161, no. 1-4, pp. 453-472, 2010.

[24] S. Giammanco, M. Ottaviani, M. Valenza et al., "Major and trace elements geochemistry in the ground waters of a volcànic area: Mount Etna (Sicily, Italy)," Water Research, vol. 32, no. 1, pp. 1930, 1998.

[25] M. Diaz, F. Pedrozo, C. Reynolds, and P. Temporetti, “Chemical composition and the nitrogen-regulated trophic state of Patagonian lakes," Limnologica, vol. 37, no. 1, pp. 17-27, 2007.

[26] S. E. Silliman, M. Boukari, P. Crane, F. Azonsi, and C. R. Neal, "Observations on elemental concentrations of groundwater in central Benin," Journal of Hydrology, vol. 335, no. 3-4, pp. 374388, 2007.

[27] H. Qian, J. H. Wu, Y. H. Zhou, and P. Y. Li, "Stable oxygen and hydrogen isotopes as indicators of lake water recharge and evaporation in the lakes of the Yinchuan Plain," Hydrological Processes, vol. 28, no. 10, pp. 3554-3562, 2014.

[28] L. Zhang and L. Wang, Groundwater Resources in Ningxia, Ningxia People Publishing House, Yinchuan, China, 2003 (Chinese).

[29] Ministry of Health of the People's Republic of China, Standards for Drinking Water Quality, GB 5749-2006, Standards Press of China, Beijing, China, 2007.

[30] Q. Y. Tang, DPS@ Data Processing System: Experimental Design, Statistical Analysis and Data Mining, Science Press, Beijing, China, 2nd edition, 2010 (Chinese).

[31] P. Willet, Similarity and Clustering in Chemical Information Systems, Research Studies Press, John Wiley \& Sons, New York, NY, USA, 1987.

[32] J. H. Wu, P. Y. Li, H. Qian, Z. Duan, and X. D. Zhang, "Using correlation and multivariate statistical analysis to identify hydrogeochemical processes affecting the major ion chemistry of waters: a case study in Laoheba phosphorite mine in Sichuan, China," Arabian Journal of Geosciences, vol. 7, no. 10, pp. 39733982, 2013. 
[33] Ministry of Geology and Mineral Resources of the People's Republic of China, "Quality standard for ground water," Tech. Rep. GB/T 14848-93, Standards Press of China, Beijing, China, 1994.

[34] H. Qian and P. Y. Li, "Hydrochemical characteristics of groundwater in Yinchuan plain and their control factors," Asian Journal of Chemistry, vol. 23, no. 7, pp. 2927-2938, 2011.

[35] M. Hussain, S. M. Ahmed, and W. Abderrahman, "Cluster analysis and quality assessment of logged water at an irrigation project, eastern Saudi Arabia," Journal of Environmental Management, vol. 86, no. 1, pp. 297-307, 2008.

[36] P. Y. Li, H. Qian, J. H. Wu, Y. Q. Zhang, and H. B. Zhang, "Major ion chemistry of shallow groundwater in the Dongsheng Coalfield, Ordos Basin, China," Mine Water and the Environment, vol. 32, no. 3, pp. 195-206, 2013.

[37] R. W. Lee, "Geochemistry of water in the Fort Union Formation of the Northern Powder River Basin, Southeastern Montana," USGS Water-Supply Paper 2076, US Government Printing Office, Washington, DC, USA, 1981.

[38] I. I. Chebotarev, "Metamorphism of natural waters in the crust of weathering-1," Geochimica et Cosmochimica Acta, vol. 8, no. 1-2, pp. 22-48, 1955.

[39] H. Qian and Z. Y. Ma, Hydrogeochemistry, Geology Publishing House, Beijing, China, 2005 (Chinese).

[40] J. Xiao, Z. D. Jin, F. Zhang, and J. Wang, "Solute geochemistry and its sources of the groundwaters in the Qinghai Lake catchment, NW China," Journal of Asian Earth Sciences, vol. 52, pp. 21-30, 2012.

[41] L. Pei-Yue, Q. Hui, and W. Jian-Hua, "Application of set pair analysis method based on entropy weight in groundwater quality assessment-a case study in Dongsheng City, Northwest China," E-Journal of Chemistry, vol. 8, no. 2, pp. 851-858, 2011.

[42] P. Y. Li, H. Qian, and J. H. Wu, "Hydrochemical characteristics and evolution laws of drinking groundwater in Pengyang County, Ningxia, Northwest China," E-Journal of Chemistry, vol. 8, no. 2, pp. 565-575, 2011.

[43] D. Marghade, D. B. Malpe, and A. B. Zade, "Major ion chemistry of shallow groundwater of a fast growing city of Central India," Environmental Monitoring and Assessment, vol. 184, no. 4, pp. 2405-2418, 2012.

[44] D. Ronen and M. Magaritz, "High concentration of solutes at the upper part of the saturated zone (water table) of a deep aquifer under sewage-irrigated land," Journal of Hydrology, vol. 80, no. 3-4, pp. 311-323, 1985.

[45] Z. H. Zhang, Study on the groundwater pollution simulation in Yinchuan Region [Master's thesis], Chang'an University, Xi'an, China, 2014 (Chinese). 

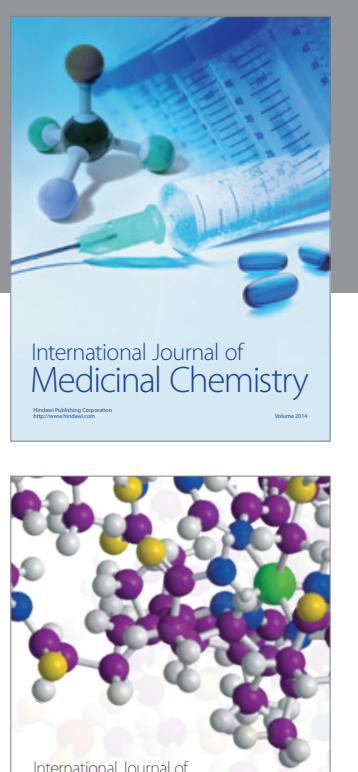

Carbohydrate Chemistry

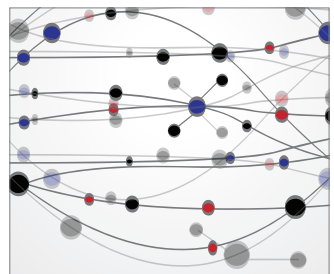

The Scientific World Journal
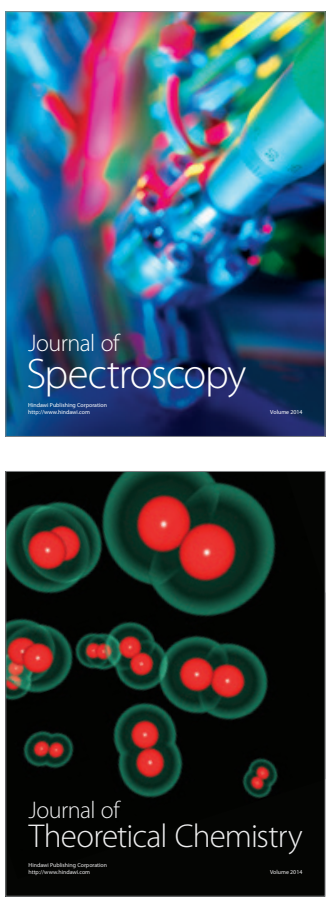
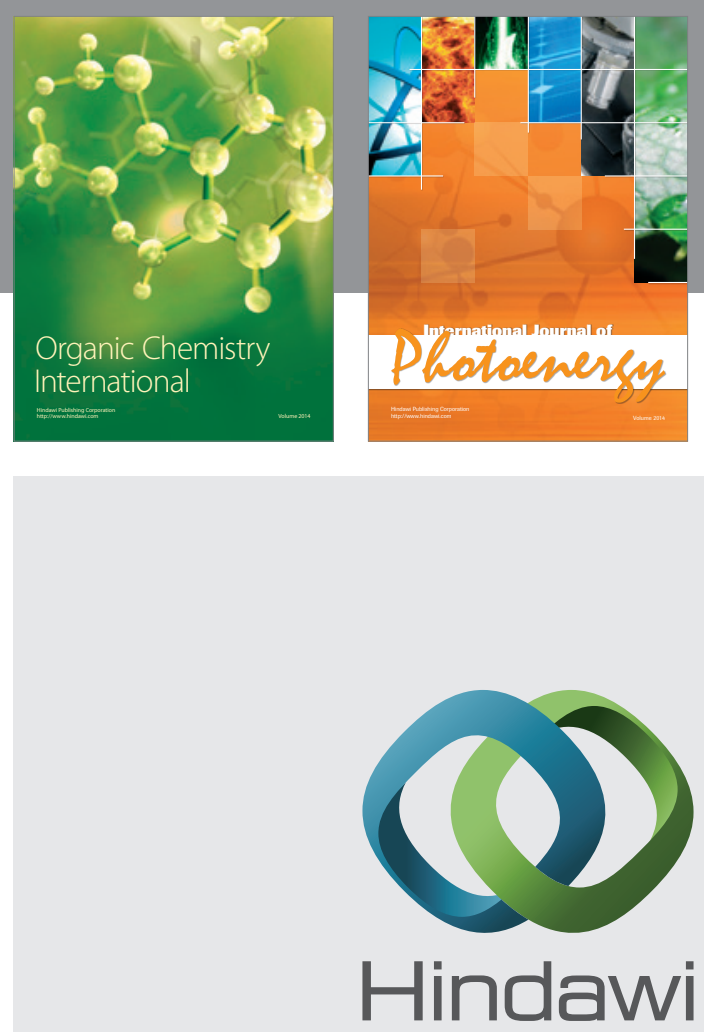

Submit your manuscripts at

http://www.hindawi.com

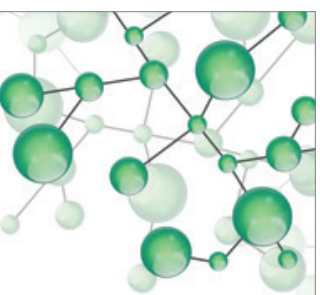

International Journal of

Inorganic Chemistry

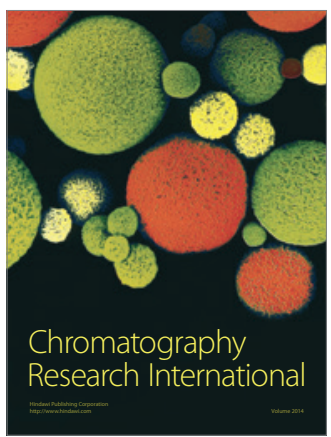

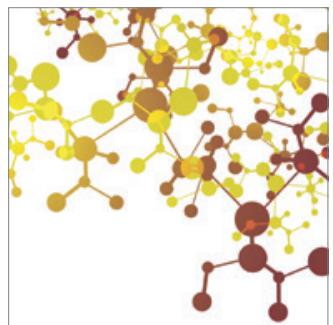

Applied Chemistry
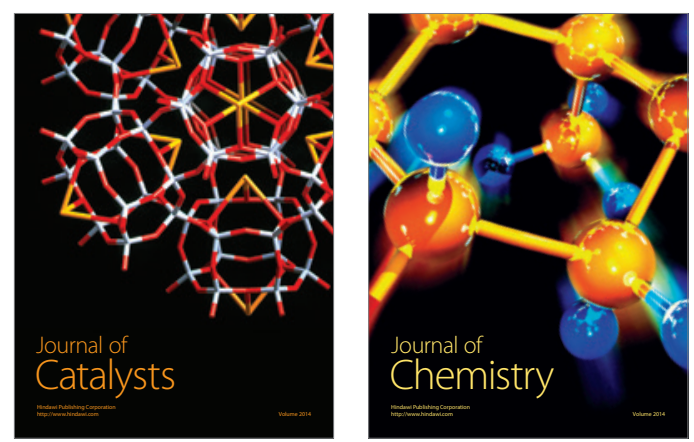
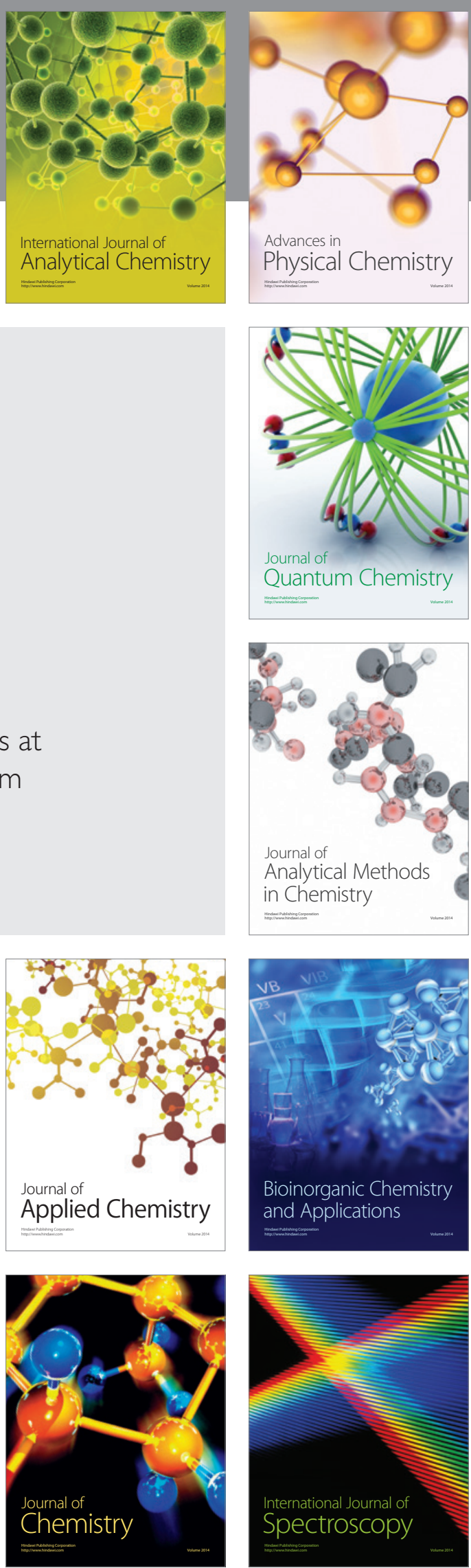